Columbia Law School

Scholarship Archive

\title{
The Agency Costs of Activism: Information Leakage, Thwarted Majorities, and the Public Morality
}

John C. Coffee Jr.

Columbia Law School, jcoffee@law.columbia.edu

Follow this and additional works at: https://scholarship.law.columbia.edu/faculty_scholarship

Part of the Business Organizations Law Commons, and the Law and Economics Commons

\section{Recommended Citation}

John C. Coffee Jr., The Agency Costs of Activism: Information Leakage, Thwarted Majorities, and the Public Morality, European Corporate GovernanCe InStitute (ECGI) LaW WorkINg PaPeR No. 373/2017 (2017).

Available at: https://scholarship.law.columbia.edu/faculty_scholarship/2057

This Working Paper is brought to you for free and open access by the Faculty Publications at Scholarship Archive. It has been accepted for inclusion in Faculty Scholarship by an authorized administrator of Scholarship Archive. For more information, please contact scholarshiparchive@law.columbia.edu. 


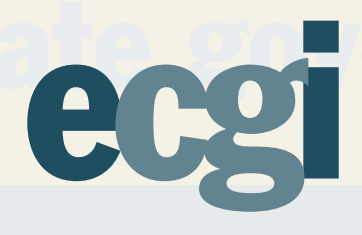

\section{The Agency Cost of Activism: Information Leakage, Thwarted Majorities, and the Public Morality}

Law Working Paper N³73/2017

November 2017
John C. Coffee, Jr.

Columbia University Law School, American

Academy of Arts \& Sciences and ECGI

(C) John C. Coffee, Jr. 2017. All rights reserved. Short sections of text, not to exceed two paragraphs, may be quoted without explicit permission provided that full credit, including (C) notice, is given to the source.

This paper can be downloaded without charge from: http://ssrn.com/abstract_id=3058319.

www.ecgi.org/wp 


\section{The Agency Cost of Activism: \\ Information Leakage, Thwarted Majorities, and the Public Morality}

Working Paper $N^{\circ} 373 / 2017$

November 2017

John C. Coffee, Jr.

The author wishes to acknowledge the valuable research assistance provided by his two assistants, Maya Ben Meir and Serdar Inci, both LL. M. students this year at Columbia Law School.

(C) John C. Coffee, Jr. 2017. All rights reserved. Short sections of text, not to exceed two paragraphs, may be quoted without explicit permission provided that full credit, including (C) notice, is given to the source. 


\begin{abstract}
Few doubt that hedge fund activism has radically changed corporate governance in the United States -- for better or for worse. Proponents see activists as desirable agents of change who intentionally invest in underperforming companies to organize more passive shareholders to support their proposals to change the target's business model and/or management. So viewed, the process is fundamentally democratic, with institutional shareholders determining whether or not to support the activist's proposals. Skeptics respond that things do not work this simply. Actual proxy contests are few, and most activist engagements are resolved through private settlement negotiations between the activists, who rarely hold $10 \%$ or more of the stock, and corporate management. Driving this process of private resolution is management's fear of ouster if they allow the matter to go to a proxy contest. But as a result, activists holding often only a small percentage of the stock are imposing their agenda on other shareholders who hold much more. Increasingly, large indexed investors -- BlackRock, State Street and Vanguard in particular -- are objecting that this pattern of private settlements excludes them. Against this backdrop, this article attempts to map the "agency costs" of contemporary activism on the premise that any new structure of governance will have its own unique agency costs. Basically, it identifies four areas in which activists have interests that can conflict with those of the other shareholders:

1. Private Benefits. Activists do receive private benefits (most notably in the form of expense reimbursement), but to date these benefits have been fairly modest (probably for a variety of reasons).

2. Information Leakage. The appointment of hedge fund nominees to a corporate board is followed by a shortterm increase in information leakage in the target firm's stock price. That is, the target firm's stock price regularly moves in the direction of a subsequent public disclosure -- and does so significantly more often and more emphatically than in the case of a control group of firms. This can most plausibly be explained as a consequence of informed trading by persons apprised of the material information that is to be released in the subsequent public disclosure. Moreover, this phenomenon of information leakage is significantly greater when the hedge fund's nominees include a hedge fund employee (as opposed to nominees who are simply independent directors). Further, once hedge fund nominees are appointed to the board, bid/ask spreads widen in comparison to the spreads on stocks in a control group.

3. Thwarted Majorities. Activists often have a short-term agenda, to which indexed investors object. Given these disagreements, it is undemocratic (even if predictable) that an organized minority can dominate a larger, more dispersed "silent majority." This is a "horizontal" agency cost in contrast to more traditional "vertical" agency costs.

4. Public Morality. Although most institutional investors favor public goals, such as greater gender diversity on the board and a shift from "dirty" to "clean" energy, activists have opposed both and are constraining the ability of public companies to behave in a manner consistent with the public morality.

Finally, this article will discuss proposed reforms intended to minimize these agency costs, without materially chilling shareholder activism.
\end{abstract}

Keywords: Activism, Agency Costs, Bid/Ask Spread, Corporate Governance, Hedge Fund, Hedge Fund Activism, Information Leakage, Informed Trading, Insider Trading, Principal Costs, Private Benefits, Private Settlements

JEL Classifications: G14, G23, G30, G32, G34, G38, K22, K41, K42, M14

John C. Coffee, Jr.*

Adolf A. Berle Professor of Law

Columbia University Law School

435 West 116th Street

New York, NY 10027, United States

phone: +12128542833

e-mail: jcoffee@law.columbia.edu

${ }^{*}$ Corresponding Author 


\section{THE AGENCY COSTS OF ACTIVISM:}

Information Leakage, Thwarted Majorities, and the Public Morality

By: John C. Coffee, Jr.

Adolf A. Berle Professor of Law

Columbia University Law School

This draft paper is to be delivered as the 2017 A.A. Sommer, Jr. Lecture on Corporate, Securities and Financial Law at Fordham University Law School on November 8, 2017

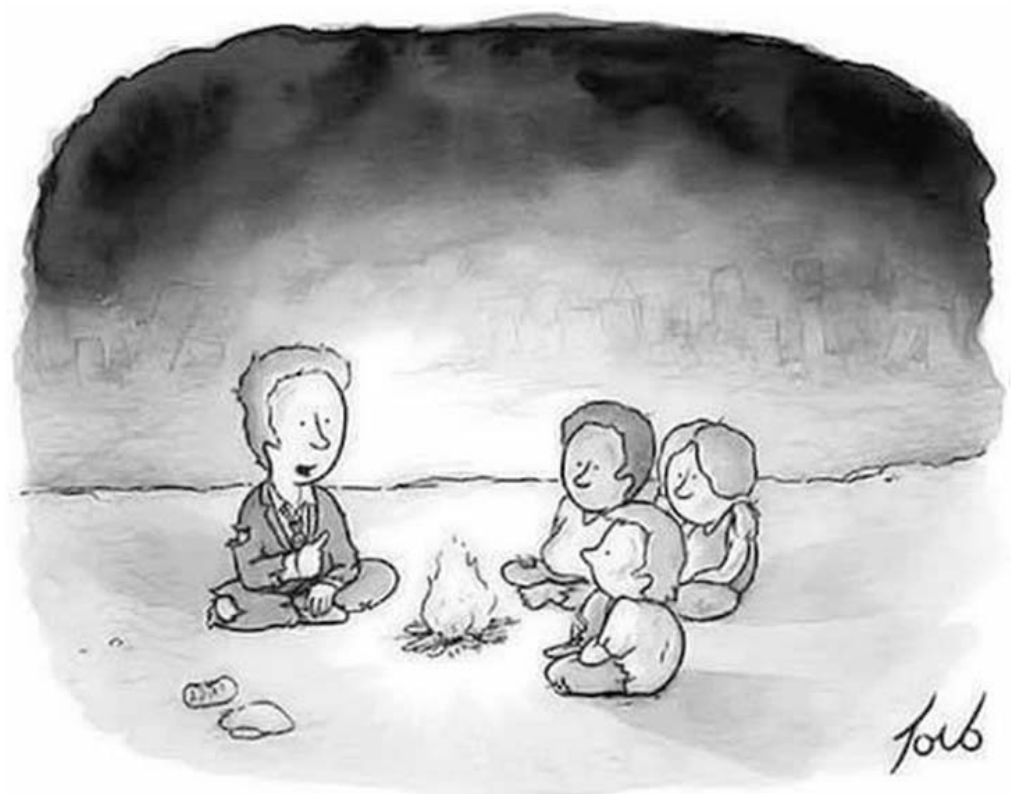
"Yes, the planet got destroyed. But for a beautiful moment in time we created a lot of value for shareholders." 
The Agency Costs of Activism:

Information Leakage, Thwarted Majorities, and the Public Morality

I. Introduction

By John C. Coffee, Jr.*

Hedge fund activism has dramatically changed corporate governance-arguably revolutionizing

it. Almost everyone agrees with this assessment, but they disagree over whether this change is for the better or the worse. The more optimistic see hedge fund activists as desirable agents of change, who intentionally invest in underperforming companies to organize the other shareholders to support their proposals (which usually seek to increase leverage and shareholder payout, trim marginal operations, and/or change senior management). ${ }^{1}$ So viewed, the process may seem a model of shareholder democracy, as the activists make proposals, managements respond, and the balance of the shareholders (who are largely sophisticated institutional investors) decide the issue. From this perspective, the result is governance by referendum, with a well-informed debate, followed by a vote. All that is new here is the appearance of an entrepreneurial intermediary (the activist hedge fund), who searches for underperforming companies, makes proposals, and lobbies the other shareholders, who hold the balance of power, to act in their mutual self-interest.

Those who are more skeptical of activism point out that things do not actually work this simply. ${ }^{2}$ In reality, there are relatively few shareholder votes on activists' proposals or director nominees. Instead, the activists and management typically settle their dispute through private negotiations, with the activist sometimes receiving private benefits not available to the other shareholders. Why does management settle rather than fight (and thus let all shareholders decide)? A key reason is that the CEO's job is imperiled,

\footnotetext{
${ }^{*}$ Professor Coffee is the Adolf A. Berle Professor of Law at Columbia University Law School and Director of its Center on Corporate Governance. The author wishes to acknowledge the valuable research assistance provided by his two assistants, Maya Ben Meir and Serdar Inci, both LL. M. students this year at Columbia Law School.

${ }^{1}$ For two leading articles taking very positive views of activism, see Ronald J. Gilson \& Jeffrey N. Gordon, The Agency Costs of Agency Capitalism: Activist Investors and the Revaluation of Governance Rights, 113 Colum. L. Rev. 863 (2013), and Lucian A. Bebchuk, The Case for Increasing Shareholder Power, 118 Harv. L. Rev. 833 (2005).

${ }^{2}$ This author should acknowledge that he would probably be classified among these skeptics. See John C. Coffee Jr. and Darius Palia, The Wolf At The Door: The Impact of Hedge Fund Activism on Corporate Governance, $41 \mathrm{~J}$. Corporation Law 545 (2016)
} 
unless he or she settles. ${ }^{3}$ Wholly apart from whether there are private benefits to the activist, this process places the activist's nominees on the board, even though it holds only $5 \%$ or so of the stock, without any majoritarian consent from the other shareholders. Often, the activist advances an agenda that may not be supported by the other shareholders. Indeed, growing reason exists to believe that diversified institutional investors and undiversified activist funds often have distinctly different agendas, and the former are beginning to object that they have been excluded from the decision-making process. From this latter perspective, one does not see the simple democracy of the Swiss canton, but instead a process of disenfranchisement. The distance between these two perspectives largely turns on the fact that private settlements may result in different outcomes than shareholder elections do, and this highlights a problem that, as will be seen, has a long history in corporate governance.

This article does not assert that one side in this debate is entirely right and the other side entirely wrong. Rather, it seeks to make and then investigate an assertion that is almost definitionally correct: a new agent (the hedge fund activist) has emerged in corporate governance, purportedly to act for all the other shareholders (or at least a majority of them). But, as new agents arise, new agency costs will also surface -- unless the agent's interests are perfectly aligned with those of the other shareholders (and this seems highly doubtful). ${ }^{4}$ Indeed, agency costs are inevitable whenever intermediaries purport to act for others - and, particularly to the extent that they possess discretion. These new costs do not mean that the process is fatally flawed, but they do suggest that some controls may be desirable because the loyalty of the agent cannot simply be assumed.

\footnotetext{
${ }^{3}$ Lazard's Shareholder Advisory Group reports that, since 2013, annualized CEO turnover at activist targets has averaged 23\% compared to 12\% for non-targets. See Lazard's Shareholder Advisory Group, Review of Shareholder Activism-3Q 2017 at 1. For the even higher rate of turnover if activist nominees go onto the board, see text and notes infra at note 47 (reporting study by FTI Consulting showing that the CEO turnover rate rises to $55.1 \%$ over two years if activists place one or more nominees on the board).

${ }^{4}$ The term "agency costs", first defined by Jensen and Meckling, refers to the costs that arise because of the use by a principal of an agent and include (1) the costs of opportunistic behavior by the agent (such as when the agent pursues its own self-interest, rather than the principal's), (2) the costs of monitoring the agent incurred by the principal, and (3) the "bonding" costs incurred by the agent to induce the principal to rely on it. See Michael Jensen and William Meckling, Theory of the Firm: Management Behavior, Agency Costs, and Ownership Structure, $3 \mathrm{~J}$. Fin. Econ. 305 (1976)_
} 
To the extent that hedge fund activists present themselves as the champion of all the shareholders, it is useful to compare this putative champion to another shareholder champion who also can behave opportunistically: the plaintiff's attorney in shareholder litigation. A plaintiff shareholder, suing, for example, for an alleged breach of fiduciary duty in a derivative action, will claim to act as the champion of all the dispersed shareholders, who themselves lack sufficient incentive to undertake costly litigation. If the litigation is successful, all shareholders should share in the recovery to the corporation, and the corporation will pay the plaintiff's costs and legal fees. In principle, this sounds like an optimal solution to the dispersion of shareholders in the public corporation. Unfortunately, however, an objective contemporary appraisal of shareholder litigation has to be more mixed. Typically, a high percentage of shareholder litigation falls into a category known as "merger objection” cases. ${ }^{5}$ Indeed, any merger involving a sizable public corporation today has a high probability of attracting litigation brought by a plaintiff shareholder, who will assert a disclosure violation or fiduciary breach-even when there is no discernible conflict of interest (as there generally is not in the standard arm's length merger). Almost invariably, these "merger objection” cases settle on a "disclosure only” basis, with no financial recovery, and with the class receiving only some additional disclosures of little value, while the plaintiff's counsel obtains a negotiated award of attorney’s fees. ${ }^{6}$ In effect, the merger is thus taxed, not by a legitimate shareholder champion or even a Robin Hood, but by a modern-day highwayman. Correspondingly, just as the plaintiff's attorney benefits mainly himself in these cases, so too in the world of hedge fund activism, activists may sometimes use private settlements to benefit themselves more than the other shareholders.

\footnotetext{
${ }^{5}$ In recent years, as many as 95\% of all mergers involving sizable public corporations have attracted shareholder litigation that asserted fiduciary or disclosure breaches. Almost all these cases settle on a non-pecuniary basis under which the defendant company agrees to make revised disclosures to its shareholders, but pays no cash award (other than attorney's fees to the plaintiff's counsel). These are known as "disclosure only" settlements. For a review of the statistics, see John C. Coffee, Jr. ENTREPRENEURIAL LITIGATION: Its Rise, Fall and Future (2015) at pages 86 to 91. Given the incentives of the target management and board to seek the highest possible price for their firm, this high litigation rate would seem to reflect not fiduciary abuse, but plaintiff's attorneys' readiness to exploit "nuisance" litigation.

${ }^{6}$ See, Jill E. Fisch, Sean J. Griffith, and Steven Davidoff Solomon, Confronting the Peppercorn Settlement in Merger Litigation: An Empirical Analysis and a Proposal for Reform, 93 Tex. L. Rev. 557 (2015).
} 
The foregoing example of "merger objection" cases is raised neither to assert that all shareholder litigation is meritless, nor to claim that hedge fund activists are regularly engaged in fraud or dubious misbehavior. But the loyalty of the shareholder champion cannot simply be assumed. To be sure, we should recognize that hedge fund activists can reduce managerial slack, can compel companies to update their business models, and can encourage them to pay out excess capital. Still, the agent may not have interests perfectly aligned with the other shareholders, and thus agency costs arise.

A roadmap for this article is now in order. After this introduction, this article will begin by attempting in to map in Part II the private settlement process surrounding hedge fund "engagements” to show how it differs from a simple democratic model. Part III will then turn to the potential agency costs that are inherent in this new process. Again, this mapping is undertaken not to demonstrate that the shareholder activist must be deterred, but more to suggest where greater controls and transparency is needed. Then, Part IV will turn to potential reforms. Here, two issues stand out: (1) Are these feasible ways to enable other shareholders to resist these private settlements when they substantially change the composition of the board?; and 2) How can the agency costs associated with this new activism best be minimized? After a century of focusing on the perceived domination of shareholders by management, American corporate law needs to focus today, at least, equally on the potential for overreaching by an organized minority of the shareholders.

Part V will then shift to broader normative concerns and intellectual history. This article's focus on the agency costs of hedge fund activism draws upon a new scholarly literature that has distinguished “vertical” agency costs from "horizontal” agency costs. ${ }^{7}$ The classic "vertical” costs were those associated with holding management accountable. But, as scholars studying venture capital have noted, conflicts can also arise among different groups of shareholders who acquired their stock at different times and with different rights. Some shareholders may be able to act opportunistically with respect to the others.

\footnotetext{
${ }^{7}$ See Robert P. Bartlett, III, Vertical Capitol, Agency Costs and the False Dichotomy of the Corporation, 54 UCLA L. Rev. 37 42-45 (2006); Simone M. Sepe, Corporate Agency Problems and Dequity Contracts, 36 J. Corp. L. 113 (2010). An alternative way to describe many of these costs is as “principal costs," caused by intershareholder conflict. See Zohar Goshen \& Richard Squire, Principal Costs: A New Theory for Corporate Law and Governance, 117 Colum. L. Rev. 767 (2017). For purposes of this article, I will not attempt to distinguish the two concepts.
} 
Similarly, as the "vertical” agency costs of corporate governance are minimized and management is made more accountable, activists at public corporations may increasingly be able to act opportunistically with respect to two other groups: (1) other shareholders who (for various reasons) have traditionally been passive, and (2) stakeholders (in particular, creditors and employees). In particular, this article will assert that a "horizontal" conflict has arisen between activists (who tend to be short-term holders) and indexed institutional investors (who tend to be long-term investors and regard themselves as the company’s “permanent shareholders”). ${ }^{8}$

As this conflict intensifies, the role of management changes. In the past, managements and boards of directors at public companies have professed that their core responsibility was to balance the interests of all stakeholders. The larger the company, the more likely that its management would take such a stance. But this balancing (to the extent that it in fact occurred) may have been at least partially a product of high agency costs that sheltered management from shareholder pressure. Once that protection is removed and management loses the discretion it once had, management and the board may come under greater pressure to transfer wealth from creditors and employees to shareholders. Indeed, abundant evidence exists that hedge fund activism has cost creditors significantly and systematically. ${ }^{9}$ In addition, some evidence suggests that shareholder pressure, organized and directed by activist hedge funds, may

\footnotetext{
${ }^{8}$ Studies differ slightly on how long the typical activist holds its stake in the "engaged" firm. One study places the median duration between a Schedule 13D filing and the activist's exit at 369 days, but a more recent study places the median duration at 266 days. Compare Brav et al., Hedge Fund Activism: A Review, 4 Found \& Trends in Fin. 204 (Feb 2010) (finding 266 day median duration) and Brav et al. Hedge Fund Activism: Corporate Governance and Firm Performance, 63 J. Fin. 1729, at 1769 (2008) (finding 369 day median duration). See also Ulf Von Lilienfeld \& Jan Schnitzler, What Is Special About Hedge Fund Activism? Evidence from 13-D Filings (Swedish House of Finance Research Paper No. 14-16 June 4, 2014) In contrast to these short-term holdings, indexed investors are relatively permanent shareholders, seldom liquidating a position.

${ }^{9}$ See for example Jory et. al., The effect of shareholder activism on bondholders and stockholders, 65 Quart. Rev. of Econ. and Fin. (2017), (finding that "activists' demands cause a significant decline in bond returns, and affect longterm bonds the most"); Feng et al., Caught in the Crossfire: How the Threat of Hedge Fund Activism Affects Creditors, http://papers.ssrn.com/sol3/papers.cfm?abstract_id=2716929 (2017)(observing that in threatened industries firms with an ex ante high likelihood of hedge fund activism experience significant losses to bondholder wealth); Klein \& Zur, Entrepreneurial Shareholder Activism, Hedge Funds and Other Private Investors, 64 J. FIN. 187 (2009)(finding that the bond returns from ten days before to one day after the filing of a 13D are negative ($3.9 \%$ ), that the average abnormal bond returns for one year after the filing date are an additional $-4.5 \%$, and that the abnormal stock returns are negatively related to the abnormal bond returns at both the short-term and long-term intervals); Klein \& Zur, The Impact of Hedge Fund Activism on the Target Firm's Existing Bondholders, 24 Rev. Fin. Stud. 1735 (2011). (finding wealth transfers and that abnormal stock returns are negatively related to abnormal bond returns).
} 
cause the corporation to act in a manner that, while lawful, is contrary to generally accepted public policies. ${ }^{10}$ From a normative perspective then, it is increasingly simplistic to view shareholders as the "good” guys, and management as the "bad”, guys when a conflict arises between them.

How one responds to this transition is at bottom a normative question, but one that brings into sharp focus the contrasts between the two major intellectual traditions in the history of American corporate governance. The first tradition is a legal one that begins with Adolf Berle and Gardiner Means, who in 1932 first identified the "separation of ownership and control” as the pivotal problem in American corporate governance. ${ }^{11}$ From that starting point, later scholars—most notably Professor Melvin Eisenberg $^{12}$ and still later the ALI Corporate Governance Project—sought to design means by which to hold management more accountable. But Adolf Berle, himself, and later the ALI Project, held the view that boards and managers should consider the public interest. Indeed, Berle believed in public-spirited managers, who-acting as "manager-statesmen"-would balance constituencies and protect the public interest. ${ }^{13}$ This idea is present, although less pronounced, in the ALI's Principles of Corporate Governance. $^{14}$

\footnotetext{
${ }^{10}$ See text and notes infra at notes 51 to 55 and 78 to 86.

${ }_{11}^{11}$ Adolf A. Berle and Gardiner C. Means, THE MODERN CORPORATION AND PRIVATE PROPERTY (1932).

${ }^{12}$ Melvin A. Eisenberg, THE STRUCTURE OF THE CORPORATION: A Legal Analysis (1976) In my view, Professor Eisenberg was the most influential corporate law scholar of the period from 1980 until recently, and his influential book was in the tradition of Professor Berle's work.

${ }^{13}$ Adolf Berle is often seen as the first proponent of shareholder privacy because of his well-known debate with Merrick Dodd. See Adolf A. Berle, Corporate Powers as Powers in Trust, 44 Harv. L. Rev. 1049 (1931); E Merrick Dodd, Jr., For Whom Are Corporate Managers Trustees?, 45 Harv. L. Rev. 1145 (1932); Adolf A. Berle, For Whom Corporate Managers Are Trustees: A Note, 45 Harv. L. Rev. 1365 (1932). But Berle's later position changed to one in which corporate managers were expected to balance constituencies and protect the public interest. For a review of his changing position, see William W. Bratton and Michael Wachter, Shareholder Primacy's Corporatist Origins: Adolf Berle and The Modern Corporation, 34 Iowa J. Corp. L. 99 (2008)(arguing that Berle later abandoned his initial position favoring shareholder primacy).

${ }^{14}$ American Law Institute, PRINCIPLES OF CORPORATE GOVERNANCE: Analysis and Recommendations (1981). Historically, the American Law Institute has sought to codify the "better" consensus view in its "restatements", and this effort was made in the ALI Corporate Governance Project. Professor Melvin Eisenberg was the Chief Reporter, and this author was also a Reporter to that Project. For Professor Eisenberg's view that the corporation may pursue non-profit maximizing objectives, see Eisenberg, Corporate Legitimacy: Conduct and Governance-Two Models of the Corporation, 17 Creighton L. Rev. 1 (1983).
} 
On the other side of this divide is the intellectual tradition of finance theory. This tradition's views were most fully formalized by Michael Jensen and William Meckling in their classic article. ${ }^{15}$ As with Berle and Means, the separation of ownership and control was placed at center stage in this article, but these authors saw this problem as controlled through the agency costs that shareholders accept to monitor management. Their article developed a model under which shareholders are the sole owners of the corporation and the only party entitled to the fiduciary duties of management and the board. Actually, current law does not require the board to maximize shareholder value, but financial economists find it difficult to believe this. ${ }^{16}$ That is, they confuse their normative view that managers should maximize shareholder value with current positive law (which imposes no such duty to maximize at present). Possibly, most directors do want to maximize shareholder value, but the Delaware Courts in particular have cautiously stopped short of mandating such a norm. ${ }^{17}$ From the economists' perspective, if management or the board can lawfully transfer wealth from stakeholders to shareholders, they should do so. Indeed, in this view, management has no business protecting creditors or employees, except to the extent that doing so creates long-term value for shareholders.

The tension between these two perspectives has long been latent, but high agency costs made actual conflicts relatively rare, because management until recently possessed close to unfettered discretion and could always claim the protection of the business judgment rule. Now, with the "vertical" costs of holding management accountable reduced by the growth in institutional ownership, these disputes will be resolved not in courts, but in the marketplace as activists challenge managements and seek board representation. Thus, this article will not attempt to articulate any new normative theory of corporate

\footnotetext{
${ }^{15}$ Michael Jensen and William Meckling, Theory of the Firm: Management Behavior, Agency Costs, and Ownership Structure, 3 J. Fin. Econ. 305 (1976).

${ }^{16}$ Whatever one's normative view, one has to recognize that managers possess great discretion under the business judgment rule. For a careful analysis of all the relevant precedents and statutes and the conclusion that managers are not under a duty to maximize profits, see Einer Elhauge, Sacrificing Corporate Profits in the Public Interest, 80 N.Y.U. L. Rev. 733 (2005). Of course, this finding does not resolve the normative debate.

${ }^{17}$ Delaware's position is clearest in its decisions permitting management to resist a hostile takeover bid at a premium. In Unocal Corp. v. Mesa Petroleum Co., 493 A. 2d 946, 955 (Del. 1985), the Delaware Supreme Court permitted managers in evaluating a lucrative takeover bid to consider "the impact on 'constituencies' other than shareholders (i.e., creditors, customers, employees, and perhaps even the community generally).”
} 
governance, precisely because such theories simply do not matter to the outcome. ${ }^{18}$ So long as (1) only shareholders vote and (2) institutional shareholder voting is controlled by managers compensated for maximizing the short-term return to their mutual or pension fund, then theories about the duties that managers owe to stakeholders, or the need for managers to consider the long-run, will have little impact. Indeed, courts may themselves be marginalized in corporate governance disputes, as the dispositive question become not how courts will rule, but how the shareholders will vote. Predictably, shareholders will vote in favor of their perceived self-interest. That said, Part V will still suggest that stakeholders have a potential ally: long-term diversified institutional shareholders, who see themselves as the corporation's “permanent shareholders,” may perceive their interests as better aligned with those of stakeholders than with those of short-term activist funds. Nonetheless, the possibility of such an alliance is hardly the assurance of one. Such an alliance faces obstacles, including finding a means to the free riders and inducing risk-averse managements to broaden the negotiations to include "permanent” shareholders when an activist appears.

\section{The Private Settlement Process}

Democracy relies on voting. But shareholder democracy today turns on private negotiations between activists and management. To illustrate, in 2016, Lazard counted some 149 campaigns initiated by activist shareholders in that year to obtain board representation, and it found that these campaigns had won a record 131 board seats in $2016 .{ }^{19}$ But $95 \%$ of these seats were the result of settlement negotiations. ${ }^{20}$ In the relatively few cases that did go to a shareholder vote, management generally won, ${ }^{21}$ suggesting that management settled whenever they saw a serious risk of losing and contested the activists' demands only when management was confident of victory (or could not strike an acceptable deal).

\footnotetext{
${ }^{18}$ This statement is not intended to deny that there are significant new theories of how managers should behave. See, in particular, Oliver Hart and Luigi Zingales, "Companies Should Maximize Shareholder Welfare, not Shareholder Value,” ECGI Working Paper 521 (2017), (available at SSRN: https://abstract=3004794) (August 1, 2017). But, such a theory will not be implemented to the extent that fund managers are compensated based on their recent returns.

${ }^{19}$ See Lazard, "Review of Shareholder Activism in 2016," at p. 1 (February 2017). The number of campaigns was down in 2016 (by 17\%) from 2015, but the number of seats won was an all-time high, suggesting that activists are becoming more successful.

${ }^{20} \mathrm{Id}$.

${ }^{21}$ In 2016 Lazard found that activists had a "win rate" in actual proxy contests of only 38\%. Id at 1.
} 
Another study by State Street Global Advisors (“SSGA”), a major institutional money manager, confirms Lazard’s findings. Surveying companies with market capitalizations above $\$ 500$ million (i.e., mid-sized companies and up), SSGA finds that less than 10\% of the board seats conceded in both 2015 and 2016 shifted through a contested proxy election. ${ }^{22}$ Instead, private negotiations dominated, and this trend is increasing. While only 10\% of conceded seats were resolved through contested elections in 2015 and 2016, 34\% of board seats conceded in 2014 were obtained through actual proxy elections, implying that in the recent past management was more prepared than today to fight a proxy contest. Put simply, management today seems increasingly risk averse, because a defeat in an election contest would be humiliating (and would likely result in its eventual ouster), while management (and its public relations professionals) can present most outcomes in negotiated settlements in a light favorable to itself. Skilled at spin control, management would rather settle than fight.

The activists leading these campaigns are a concentrated group of repeat players, with Table 1 below showing that ten well-known activists won 76 seats—or a clear majority of the 131 seats conceded in $2016:^{23}$

\section{Table 1}

\footnotetext{
${ }^{22}$ See, State Street Global Advisors, "Protecting Long-Term Shareholder Interests in Activist Engagements" (October 10, 2016) at 1.

${ }^{23}$ See Lazard, supra note 3, at 4. Elliott initiated the most campaigns (13), but won fewer seats than Starboard Value. Id.
} 


\begin{tabular}{|c|c|c|c|}
\hline \multicolumn{4}{|c|}{ Most Board Seats Obtained² } \\
\hline \multirow[b]{2}{*}{ Activist } & \multicolumn{2}{|r|}{2016} & \multirow{2}{*}{$\begin{array}{r}2015 \\
\text { Rank } \\
\end{array}$} \\
\hline & \# of Board Seats Won & Avg. Mkt Cap. of Targets ${ }^{1}$ & \\
\hline Starboard Value & 21 & $\$ 10,267$ & 1 \\
\hline Elliott & 12 & 47,026 & 2 \\
\hline Icahn & 9 & 30,105 & 3 \\
\hline Engaged Capital & 8 & 773 & 8 \\
\hline JANA & 7 & 6,314 & 5 \\
\hline Pershing Square & 6 & 19,423 & 19 \\
\hline Glenview & 4 & 2,300 & - \\
\hline Altimeter/PAR & 3 & 17,313 & - \\
\hline Barington & 3 & 1,120 & 13 \\
\hline Lucus (Red Alder) & 3 & 671 & - \\
\hline
\end{tabular}

The majority of the seats filled by activists go to persons resembling traditional independent directors, but Lazard found in 2016 that $27 \%$ of contested board seats went to employees of the activist fund. ${ }^{24}$ This statistic is important for a number of reasons, including that there appears to be greater information leakage when hedge fund employees are placed on the board (as later discussed).

On balance, the rate of hedge fund activism is increasing. Although the number of activist campaigns fell somewhat in 2016, the actual number of seats won by activists increased. ${ }^{25}$ The even more significant statistic may be the number of new entrants into this field. Lazard found that 37 activist investors initiated activist campaigns for the first time in $2016 .{ }^{26}$ This increase suggests that these firsttime activists saw profits to be made from the activity of activism and joined the parade.

As earlier noted, activist campaigns generally result in a settlement, which is usually embodied in a settlement agreement. These agreements, which are typically (but not always) filed with the SEC, have seldom been studied. One large scale study has been recently released by Professor Lucian Bebchuk and

\footnotetext{
${ }^{24}$ Lazard, supra note 3, at 1.

${ }^{25}$ Id.

${ }^{26} \mathrm{Id}$.
} 
several colleagues, ${ }^{27}$ but it goes only until 2011, and much has changed since then. Typically, these settlement agreements will address a number of topics, including board composition, standstill provisions, expense reimbursement for the activist, “non-disparagement” provisions, and, possibly, confidentiality provisions (which may or may not restrict the new director or director nominee from sharing information learned at board meetings with others, including the hedge fund). Such provisions, as next discussed, raise the possibility that the hedge fund activist may receive benefits not available to other shareholders.

A principal conclusion of the Bebchuk study is that these agreements do not address the business operations or policies of the corporation, but rather focus only on the composition of the board. ${ }^{28}$ Bebchuk and his colleagues conclude that this shows the efficiency of "incomplete contracting." Those more experienced in corporate law would recognize that there is a simpler (if theoretically less elegant) explanation for this focus: directors, as fiduciaries, cannot contract away their discretion. As many cases have held, a contract binding the director, for example, to vote for increased dividends or a share buyback would be unenforceable. ${ }^{29}$ Instead, the settlement agreement must focus on what can be agreed upon: namely, how shareholders will vote for directors and which directors will agree to resign. "Incomplete contracting," at least as an explanation for the structure of settlement agreements, works better in the hothouse of academia than in the real world.

In any event, it is clear that, in a high majority of settlement agreements, new directors are added to the board, usually through an expansion of the board's size. ${ }^{30}$ According to the Bebchuk study, the median number of directors so added is two (although, in at least a few recent cases, majority slates of

\footnotetext{
${ }^{27}$ See Lucian A. Bebchuk, Alon Brav, Wei Jiang and Thomas Keusch, Dancing With Activists (2017).

${ }^{28}$ Id at 4.

${ }^{29}$ For early leading cases, see McQuade v. Stoneham, 263 N.Y. 323189 N.E. 234 (1934); Long Park, Inc. v. Trenton-New Brunswick Theatres Co., 297 N.Y. 174, 77 N.E. 2d 633 (1948). New York does permit closely held corporations to opt out of this rule by a charter provision, but there is no exception applicable to publicly held firms. See N.Y. Bus. Corp. Law §620(b).

${ }^{30}$ The study by Professor Bebchuk and his colleagues finds that new directors are added in $87.4 \%$ of the settlements they surveyed and some incumbent directors leave the board in $40.77 \%$ of these settlements. See Bebchuk, supra note \#, at 21. Thus, the board will typically need to be expanded, which can ordinarily be done by bylaw or board resolution if the corporate charter so authorizes.
} 
directors nominated by activists have been elected, giving the activist fund de facto control). ${ }^{31}$ The only other provision that is nearly universal is a standstill provision. ${ }^{32}$

Sometimes, these agreements provide opportunities for self-dealing by the activist because its interests can conflict with, or at least differ from, those of the other shareholders. To give a well-known example, Sotheby's, the art auction house, was engaged in 2014 by Third Point LLC, a leading activist hedge fund, founded by Daniel S. Loeb, one of the highest profile hedge fund activists. Third Point commenced a proxy fight seeking to place three directors on Sotheby's board, but, on the eve of the shareholder meeting (just before when the voting outcome would have been announced), Third Point settled in part for a $\$ 10$ million payment by Sotheby’s as reimbursement of Third Point’s expenses. ${ }^{33}$ Because Sotheby's, itself, reported that it had incurred expenses of only \$5.7 million in opposing Third Point's campaign, this payment of \$10 million to Third Point surprised observers and arguably may have been overly generous. To be sure, Third Point also negotiated the appointment of the three directors that it had originally sought, but the question remains: Was anything traded for this $\$ 10$ million payment? No conclusion is here expressed, because the relevant point is only that the interests of Third Point and the other shareholders could conflict. A tradeoff between management and the activist in such a setting is easy to imagine.

The costs incurred by activists are growing. In the recent and unsuccessful campaign by the Trian Fund to place Nelson Peltz, its founder, on the Proctor \& Gamble (“P\&G”) board, Trian estimated its expected costs at $\$ 25$ million, but acknowledged that they could run higher. ${ }^{34}$ Had Trian assembled a majority block to support its candidate in advance of the shareholders' meeting, P\&G could have sought a

\footnotetext{
${ }^{31}$ For the finding that the median number is two, see Bebchuk, supra note 27, at 17. Still, this study does note that in 17 cases, the number elected was four or more. In 2016, well after the 2011 end date of the Bebchuk study, Mantle Ridge, an activist fund, elected a majority slate of directors to the board of CSX. Corp. and brought in a new CEO, even though Mantle Ridge held only around a 5\% stake in CSX.

${ }^{32}$ Bebchuk and his colleagues also describe a "standstill” provisions as "almost universal" (Id at p.6 ) and observe that there can be two types of standstill provisions: (1) a limitation on share ownership by the activist, and (2) a "corporate governance standstill" under which the solicitations of proxies or other actions are halted. Id at 6.

${ }^{33}$ See Alexandra Stevenson, “Sotheby’s to Reimburse Loeb \$10 Million,” New York Times, May 7, 2014.

${ }^{34}$ This estimate was made by Trian in its proxy statement, which conceded that actual costs could prove higher. See also, http://money.cnn.com (2017/10/10/new/companies/procter-gamble-proxy-fight/index.html).
} 
private settlement with Trian that reimbursed Trian's expenses. This, of course, raises the issue of what P\&G might have asked for in return. ${ }^{35}$

Other conflicts also inevitably exist. When the hedge fund designates a director or directors (some of whom may be hedge fund employees), it will typically remain in close contact with its appointed directors and will likely obtain material, non-public information from them. ${ }^{36}$ Potentially, the hedge fund could use that information itself, or it could pass it onto allies. This behavior, depending on its facts, may or may not be unlawful under the federal securities laws, or under Delaware law, but regardless, it is an agency cost to the extent it injures the corporation or widens the bid/ask spread. The issue of legality will be delayed until later, but the potential conflict could not be clearer.

A final area where there may be a "horizontal" conflict between the interests of the activist and the other shareholders involves the choice and agenda of the new directors. Diversified institutional shareholders, possibly holding even more stock, might prefer different directors with very different objectives. Recently, BlackRock, Inc. the world's largest investment manager, the Vanguard Group, another of the world's largest investment managers, and SSGA, also a very sizeable investment manager, have all publicly criticized hedge fund activists and the recent settlement process, suggesting that they perceive themselves as having been excluded by these private agreements from the role they deserve as “permanent shareholders”, often holding more stock than the activists. ${ }^{37}$ Professor Bebchuk and his colleagues discount these criticisms, because they find that the nominees selected by activist hedge funds do not receive a lesser vote in subsequent director elections. The problem with this analysis, however, is

\footnotetext{
${ }^{35}$ There are many things that corporate management might want in return for reimbursement, including: (1) a standstill agreement under which the activist agrees not to buy more stock or launch any proxy fight, and (2) a nondisparagement agreement under which the activist agrees not to criticize management publicly. Both are common provisions in settlement agreements.

${ }^{36}$ Delaware law does impose a duty of confidentiality on directors. See, e.g., Shocking Technologies v. Michael, 2012 WL 4482838 at *10 (Del. Ch., October 1, 2012) (finding director breached duty of loyalty by providing confidential information to investor); see also Henshaw v. American Cement Corp., 252 A. 2d 125 (Del Ch. 1969). Still, a respected Delaware Vice Chancellor has recently opined that "directors are on solid ground when resisting confidentiality agreements" and probably may share information learned at board meetings with the hedge fund that nominated them and with related colleagues. See J. Travis Laster, The Rights and Duties of Blockholder Directors, 70 Bus. Law 33 48-51 (2014). As later discussed, such sharing appears to be common and seemingly results in broad information leakage.

${ }^{37}$ For SSGA's objections, see note 22 supra.
} 
that the Bebchuck study covers results only through 2011, and these large diversified investors began voicing their concerns and criticisms only more recently in 2015 and 2016. Thus, it remains a very open and debatable issue whether this process is benign.

All that need be concluded at this stage is that activists will usually resolve their differences with the firms they engage through private negotiations that typically change the composition of the board. In the aftermath, the CEO will frequently depart. ${ }^{38}$ This process clearly does focus on underperforming firms, but it has begun to trouble much larger institutional investors, who consider themselves the target corporation’s “permanent” shareholders.

\section{Agency Costs: A Brief Tour}

It is possible to hypothesize a variety of ways in which that the activist hedge fund can gain private benefits not available to other shareholders or can act contrary to the wishes of the majority of the shareholders because of the leverage it possesses. The empirical evidence is still limited, but enough exists to raise serious concerns. Let us begin with a brief survey:

\section{A. Private Payments}

It is not uncommon for a corporation “engaged” by an activist hedge fund to agree to reimburse the fund for the expenses that the fund allegedly incurred in connection with the engagement. These expenses might include SEC filing fees, legal expenses, or the costs of an actual proxy campaign (if one was conducted or if a draft proxy statement was prepared). Here, the Sotheby's campaign stands out with its $\$ 10$ million payment to Third Point.

How typical is such a large payment? The Bebchuk study includes no findings on this issue, but I am currently involved with an effort to tabulate data on 475 settlement agreements extending up to 2015. I will not here release any of the findings of that study, but payments on the same order of magnitude as that paid by Sotheby's to Third Point are rare. Although reimbursement is not uncommon, the amounts so

\footnotetext{
${ }^{38}$ The Bebchuk study finds that $18.6 \%$ of CEOs depart within a year after the settlement agreement (although only about 3\% of such agreements provide for the CEO's departure). See Bebchuk, supra note 27, at 16. A more recent study by FTI Consulting places the departure rates for CEO's after activist nominees are added to the board at $34.1 \%$ and $55.1 \%$ over one and two years, respectively, following these appointments. See Sonali Bazak and Beth Jinks, “Activist Directors Double Chance of CEO exits, study shows,” Bloomberg News, October 12, 2016
} 
paid are usually modest. Because significant and legitimate legal expenses are incurred by activists in conducting engagements, this may suggest that activists feel constrained in seeking reimbursement by a fear of reputational damage if they disclosed a substantial payment. Alternatively, the activist may want to proclaim that it made such a large profit on its engagement that it does not need to be concerned with penny-ante matters, such as expense reimbursement. Of course, it is conceivable that some activists may receive a sizable payment, but fail to report it on the ground that it is not financially material. Still, this seems unlikely for a variety of reasons. ${ }^{39}$

What does the corporation gain for its payment? Possibly, the corporation may negotiate a standstill provision and/or a "non-disparagement” provision in the settlement agreement. These provisions, which are very common in settlement agreements, bar the activist from acquiring more shares, launching a proxy contest, or voicing public criticism of the corporation and its management for the duration of the agreement. Arguably, the activist, as champion of the shareholders, is silenced.

Other forms of payments are also possible. Earlier this year, Mantle Ridge Partners, LP, a newcomer to hedge fund activism, conducted an extraordinarily successful engagement with CSX Corp. Although holding less than 5\% of CSX's stock, Mantle Ridge was able to secure the appointment of four of its nominees to the CSX board, including a new CEO, E. Hunter Harrison, who brought with him a new strategic plan for CSX. Effectively, Mantle Ridge and its new CEO engineered a palace coup d'etat at CSX. Then, Mantle Ridge asked shareholders to approve the CEO’s pay package in an advisory vote at CSX’s annual shareholder meeting, which package included an \$84 million reimbursement to Mantle Ridge of the compensation and benefits forfeited by Mr. Harrison when he resigned as CEO of Canadian Pacific to take the position at $\mathrm{CSX} .{ }^{40}$ Although the transaction produced a major stock price jump in CSX's stock, others have noted the shareholders had little choice, as Harrison had indicated that he would

\footnotetext{
${ }^{39}$ One reason is that management of the target would also need to make a disclosure about the settlement agreement, and the possibility that both would agree not to disclose the payment seems small in my judgment.

${ }^{40}$ For a description of this contest, see "CSX CEO Hunter Harrison's Pay is No Great Train Robbery,” Fortune, March 24, 2017. The payment went to Mantle Ridge, as it had earlier reimbursed Mr. Harrison. CSX's shareholders did vote by a wide margin to approve this payment in an advisory vote; thereafter, the CSX board made the legally binding decision to approve the payment. See Michael Flaherty, "CSX shareholders approve \$84 million reimbursement to Mantle Ridge,” Reuters Business News, June 5, 2017
} 
resign if the reimbursement was not ratified by CSX's shareholders. ${ }^{41}$ Because Harrison's resignation might have produced a stock price decline that erased the earlier gain, CSX's shareholders were faced with Hobson’s choice.

Cases such as CSX show both that shareholders may be pressured to ratify steps taken by their activist champion and that shareholders can earn extraordinary stock gains from activism. Obviously, shareholders want to reduce agency costs without eliminating the shareholder gains, and a balance needs to be struck.

B. Information Leakage

An important study by my colleagues Robert Jackson and Joshua Mitts, along with Robert Bishop, finds that the appointment of activist nominee or nominees to a corporate board is followed by a short-term increase in information leakage into the target's stock price. ${ }^{42}$ That is, once activists' nominees are placed on the board, the stock price of the targeted corporation moves in advance of the disclosure of material information in the direction that this disclosure produces. In short, the market anticipates the later corporate disclosure. The most plausible explanation for this pattern is that informed trading by those with access to material, nonpublic information is decoded by other traders to imply an approaching gain or loss.

Specifically, this study concluded that:

(1) The appointment of activist-nominated directors "causes material information regarding the firm and its operations to become more 'leaky'; that is, more of that information makes its way into the company's stock price prior to the disclosure of that information than in two groups of control firms we use;",43

\footnotetext{
${ }^{41}$ In a review of the transaction, Cleary Gottlieb observed that "a reasonable argument can be made that the shareholder vote is...a veneer to shield the board from a tough call.” See Arthur H. Kohn, Ethan A Klingsberg, Elizabether K. Busher \& Robin Bissell, Cleary M\&A Corporate Governance Watch "Balancing Concessions and Activist Against Responsiveness to the Broader Shareholder Base,” [date].

${ }^{42}$ Robert E. Bishop, Robert J. Jackson, Jr. and Joshua R. Mitts, "Activist Directors and Information Leakage” (2017). This study is acknowledged in a footnote in the Bebchuk study, but those authors decline to discuss it. See Bebchuk, supra note 27, at $4 \mathrm{n}$. 4. Its relevance to their benign view of hedge fund activism is, however, undeniable. ${ }^{43}$ Id at $1-2$.
} 
(2) “[T]he increased leakiness is associated with the appointment of directors who are also employees of the activist investor - that is, finance professionals - as opposed to the industry experts sometimes appointed to the target's board pursuant to an activist settlement;" ${ }^{44}$ and

(3) “[B]id-ask spreads grow significantly as a result of the appointment of activist directors...,45

Much of this data is complex and not easily summarized here, but the impact on the bid/ask spread is easily illustrated. Figure 7 from their study, shown below, plots the average bid/ask spread divided by the closing price of each firm in both the treatment and control group, both prior to and following the activist intervention (i.e., the appointment of a board member or members): ${ }^{46}$

\section{Figure 7. Parallel Trends: Bid-Ask Spreads}

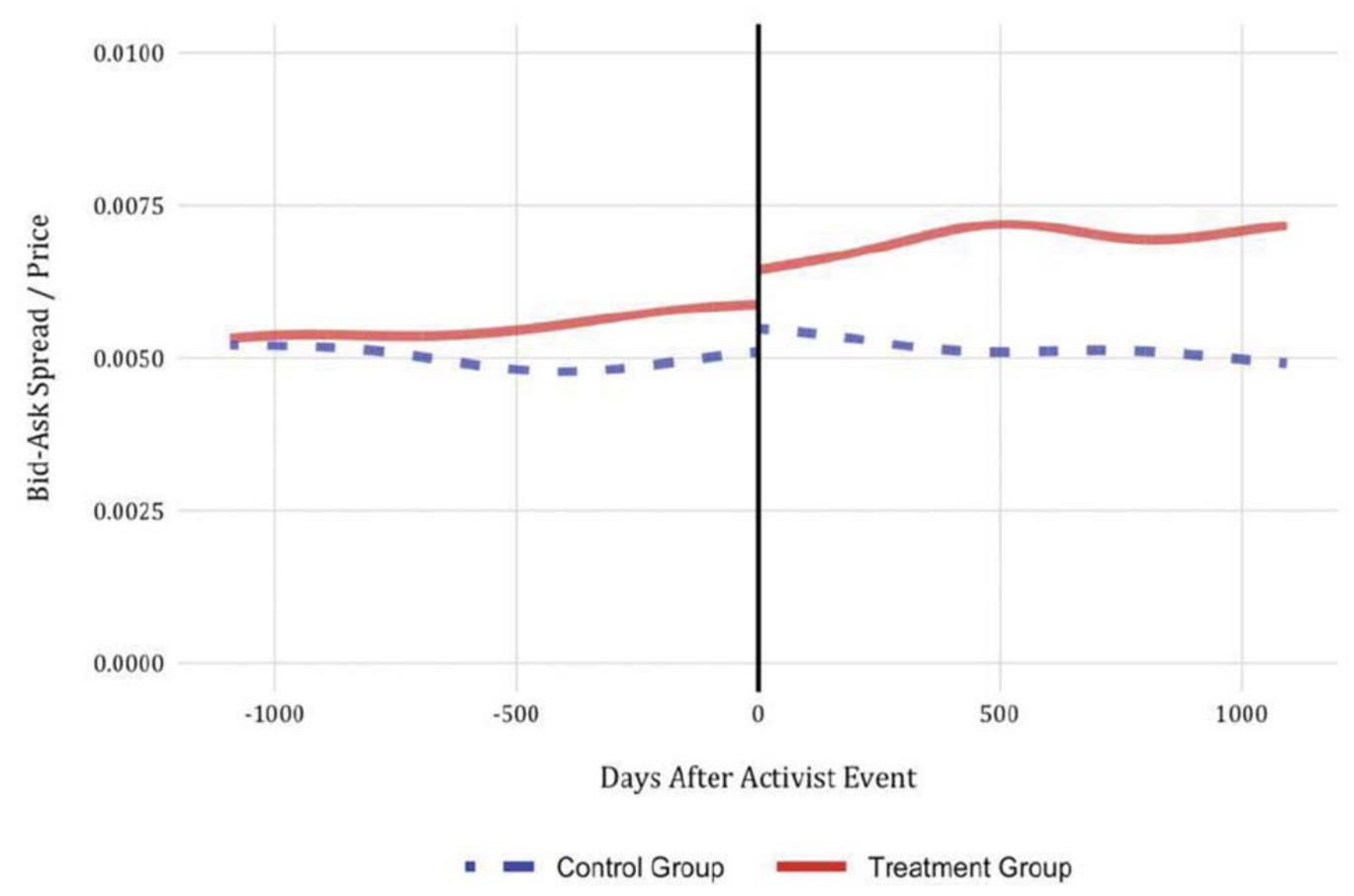

As this figure shows, the trends are approximately parallel prior to the intervention, but they diverge thereafter as the spreads increase for the treatment group.

\footnotetext{
${ }^{44}$ Id at 2.

${ }^{45} \mathrm{Id}$.

${ }^{46}$ Id at Figure 7.
} 
Because this study was based on a data set of 475 settlements, extending over a fifteen-year period and continuing up until 2015, ${ }^{47}$ it furnishes compelling evidence that activist engagements are associated with information leakage and widened bid/ask spreads-most clearly in cases where a fund employee goes on the board. This differential between the "inside" fund employee and the "outside" expert should not be surprising, as the former simply has more reason to leak or tip (and probably more actively trading friends and colleagues). Still, one must be careful here not to claim too much; this study does not prove that activist funds are engaged in unlawful insider trading or that they are tipping others (even negligently) who engage in informed trading. For our purposes, the legality of this trading is not the immediate issue. From an agency cost perspective, the cost to shareholders is the same whether the widened spread was produced by unlawful tipping or simply negligent handling of the confidential information.

The implications of this study are particularly important in understanding what is driving hedge fund activism. If activist engagements culminating in the appointment of fund-nominated directors are followed by informed trading (whether or not unlawful), then activism is receiving a subsidy. Subsidies logically increase the level of the subsidized activity. That is, any subsidy to hedge fund activism would logically encourage an increase in the number of activist engagements, even if these engagements do not produce value for the other shareholders. To illustrate, suppose an activist fund expends $\$ 100,000$ in expenses (which are not reimbursed) over a six-month period and eventually appoints two directors to the target's board. Assume further that the stock price moves up and down in a volatile fashion over the six month period following their appointment to the board, but ultimately no long-term increase in the target's stock price results. Shareholders in this target thus gain nothing (and probably bear some costs in the form of the legal expenses incurred by their company and the diverted executive time). Still, the activist (or its allies) make $\$ 500,000$ in profits from informed stock trading in the secondary market over this interval. As a result, the entire transaction produces no gain for shareholders generally (and probably

\footnotetext{
${ }^{47}$ Id at 1.
} 
some social waste), but it does yield a significant private benefit. When private gains cause public waste, the result is socially inefficient.

The bottom line is that access to material, non-public information gives rise to an invisible subsidy to activism that logically both inflates the rate of activist engagements and encourages inefficient engagements that do not generate value for the other shareholders (but do generate profits for informed traders). Again, this does not mean that hedge fund activism is itself undesirable or inefficient, but only that it is receiving a perverse subsidy.

Still, who benefits and how is this subsidy allocated? Normally, the activist signs a standstill agreement with the target firm ${ }^{48}$ But this may be less a barrier than it first appears, for several reasons: First, a standstill agreement would not, without more, prevent shortselling or trading in put and call options (which are the least costly way of exploiting material non-public information). Second, although private settlement agreements vary substantially in the restrictions they impose, most do not expressly bar trading by the activist or its employees, and relatively few require the target company's consent to the sharing of confidential information. ${ }^{49}$ Instead, they typically recite a formula that the activist will obey the law. $^{50}$

Even if not contractually constrained, the activist firm may not dare trade, itself, in the target’s stock for fear of legal exposure, but its employees and allies may feel less constrained. Possibly, they may trade through hidden agents. If the hedge fund or its employees share material, nonpublic information acquired from access to the target's board with the fellow members of its "wolf pack" of allies, such trading by these allies would be both harder to detect and legally more difficult to prosecute.

Alternatively, employees of the hedge fund may just enjoy gossiping with their professional colleagues at

\footnotetext{
${ }^{48}$ As noted earlier, the Bebchuk study finds that a standstill provision in settlement agreements is "almost universal.” Bebchuk, supra note 27, at p. 6.

${ }^{49}$ I will not reveal the results of our survey of 475 settlement agreements here, but only a small number actually require the company's specific consent to the sharing of confidential information.

${ }^{50}$ Often, the settlement agreement will provide: "Each investor acknowledges that it is aware that the United States securities laws prohibit any person who has received material, non-public information concerning the Company from purchasing or selling." Other times, the provision will require only that the activist fund inform persons with whom it shares the information that it is confidential information, which the recipient may be restricted from using or sharing.
} 
other firms, possibly anticipating that their sharing of information will earn them reciprocal favors in the future. This implicit view of Wall Street as a giant “favor bank” in which a norm of reciprocity prevails seems consistent with the facts of some recent cases, including Newman.$^{51}$ Finally, the activist fund's tipping might be perfectly lawful. For example, if the activist fund secures a promise of confidentiality from an ally (e.g., another activist investor), it can share confidential, nonpublic information with it and indeed may have a legitimate corporate purpose for so doing. ${ }^{52}$

The activist fund's motivation to share material, non-public information is easy to understand. By itself, it typically holds considerably less than $10 \%$ of the target's stock (usually more like $6 \%$ to $7 \%$ ). From such a base, it has only a modest advantage over management in a proxy fight. But if it can assemble a "wolf pack" coalition holding $20 \%$ or more, it has a substantial advantage, and management would have to win $62.5 \%$ of the remaining vote (on these facts) to stave off defeat. Why do allies flock to support an activist fund? One answer may be that access to material, non-public information is a powerful incentive. Even if these “wolf pack” allies doubt the logic of the activist’s proposals, they may still anticipate that they can profit from early access to undisclosed material information. Moreover, it is logical to anticipate that there will be market-moving announcements in the near future, given the activist’s plans. In all likelihood, most of the “wolf pack” allies will agree with the activist fund’s proposals, but the key point is this: access to nonpublic information offers "wolf pack" members an attractive, short-term return, even if the activist's proposal proves flawed or is rebuffed. The allies in the “wolf pack” can profit, regardless of whether the activist’s plans fizzle, are abandoned, or blocked.

\footnotetext{
${ }^{51}$ In United States v. Newman, 773 F. 3d 438 (2d Cir. 2014), the defendants were fourth and fifth level "remote" tippees, and the information moved from employees in one firm to those in another firm, seemingly as a gift. Although Newman is no longer good law in light of later decisions, the fact pattern illustrates how information flows within the industry.

${ }^{52}$ For example, if the activist fund is trying to organize a proxy contest, it may be in the best interests of the fund's investors for its managers to share information with prospective allies (at least if it secures a promise of confidentiality). The goal of winning a proxy fight requires it to search for allies and explain its reasoning. Regulation Fair Disclosure explicitly recognizes that material non-public information may be shared with those who agree to preserve its confidentiality. See Regulation FD, 17 CFR § 243.100(b)(2)(ii) (providing that Regulation FD does not apply to a disclosure to a person "who expressly agrees to maintain the disclosed information in confidence"). Of course, those who promise confidentiality may not comply (or they may tip still others who do not comply).
} 
Of course, we do not know that the activist's allies in the "wolf pack" think or behave in this way. But we do know that someone is trading actively and disproportionately once a hedge fund insider goes on the board. Equally important, we know that the market expects such trading, which is why the bid/ask spread widens on the appointment of a hedge fund employee to the board. To ignore the market's reactions is to wear a self-imposed blindfold.

To sum up, even if we do not know whether illegality is occurring, we have evidence that there is a perverse subsidy fueling hedge fund activism. The gains to those engaged in informed trading are matched by an agency cost to other shareholders: namely, the widening of the bid/ask spread. In fairness, one cannot yet estimate the size of this subsidy. All that is clear is that the desire for access to nonpublic information is strong and could motivate some to join a "wolf pack" and support the lead activist, even if the activist's proposals struck them as illogical or infeasible. Access to nonpublic information could be the social cement that holds together an otherwise unstable "wolf pack," because those desiring information in advance of its release to the market need to stay in the wolf pack to gain access.

\section{The Impact on Board Diversity.}

Much evidence exists that hedge fund activism is retarding or reversing the movement towards greater board diversity. The data is fairly clear. A recent white paper by Institutional Shareholder Services (“ISS”) and the Investor Responsibility Research Center Institute (“IRRC”) analyzed 380 directors appointed between 2011 and 2015 as the result of settlement agreements or in response to activist pressure. ${ }^{53}$ Only $8.4 \%$ of these directors were women (as opposed to $28.9 \%$ of new directors at S\&P 500 firms), and only $4.6 \%$ were persons of color, and only one minority female director was appointed out of those 380 appointments. $^{54}$

Although the adverse impact on the goal of diversity is clear, there can be more debate about whether this should be regarded as an agency cost. If one believes greater board diversity is a means

\footnotetext{
53 See Andrew Borak, Zachary Freisner \& Patrick McGurn, “The Impact of Shareholder Activism on Board Refreshment: Trends in S\&P 1500 Firms” (2017) (study by ISS and IRRC).

${ }^{54}$ Id at 16. For further evidence, see also George Tepe, "Boards Should Use Diversity As a Defense Against Activists,” The CLS Blue Sky Blog, September 21, 2017.
} 
towards maximizing shareholder value, this is an agency cost. Conversely, if one believes that some institutional investors are exposed to political pressure from ideological activists and, as a result, only mouth an insincere preference for diversity, there is no agency cost here. But, based on their public statements, even private institutional investors (who are exposed to much less pressure than a public pension fund) have come to support greater diversity. ${ }^{55}$

Phrased more broadly, the potential agency cost here is that the majoritarian preference is being thwarted. As next seen, this example is a special case of a more general phenomenon: activism may be frequently preempting the majority’s preferences.

\section{Preempting the Majority's Preference}

The heyday of hedge fund activism began a decade or so ago when traditional institutional investors (who are typically diversified, often indexed, and generally passive) began to support the proposals advanced by activist hedge funds. That support enabled hedge funds typically holding less than $10 \%$ of an issuer's stock to compel management to negotiate with them for fear of otherwise losing a hostile proxy fight in which the diversified institutional investors would vote to support the undiversified hedge funds.

But more recently, that alliance has come under strain. A fissure has clearly developed between hedge fund activists and an institutional investor community that fears the short-term bias of activism. Originally, major diversified institutions attacked the goals of the activists. The CEOs of BlackRock and Vanguard sent much publicized letters in 2015 to their fellow CEOs at large-cap companies, urging them not to take the short-term view advocated by activist hedge funds. ${ }^{56}$ Then in 2016 , these institutions and

\footnotetext{
${ }^{55}$ A host of major institutional investors, including BlackRock, Vanguard and SSGA, have issued statements endorsing greater gender and racial diversity on boards and have justified movement in this direction as intended to maximize shareholder wealth by improving board decision-making. See, e.g., BlackRock, Inc., "Our Engagement Priorities for 2017-2018,” http://www.BlackRock.com/corporate/en-us/about-us/investmentstewardship/engagement-priorities; State Street Global Advisors, "SSGA’s Guidance on Enhancing Gender Diversity on Boards” (March 7, 2017), https://:www.ssga.com/investment-topics/environmental-socialgovernance/2017-guidance-on-enhancing-gender-diversity-on-boards.pdf.

56 See for example Larry Fink’s 2016 Corporate Governance Letter to CEOs (https://www.blackrock.com/corporate/en-no/literature/press-release/2016-larry-fink-ceo-letter.pdf) and his Annual Letter 2017 (https://www.blackrock.com/corporate/en-no/investor-relations/larry-fink-ceo-letter); see also Vanguard
} 
others agreed with major corporations on statements of corporate governance principles that again sought to shift the focus away from short-term results. ${ }^{57}$

Later in 2016, State Street Global Advisors (SSGA) shifted the focus from substantive goals to procedures, releasing an elaborate statement criticizing the willingness of corporations engaged by activists to enter into quick and private settlements with activists without first seeking the input of longterm shareholders (such as, of course, themselves) ${ }^{58}$ SSGA was clearly on to something here; it saw that risk averse managers would rather concede two directors to activists than take the risk of a hostile proxy contest and possibly a humiliating defeat. As SSGA pointed out, less than $10 \%$ of board seats conceded in activist campaigns in 2015 and 2016 had resulted from a proxy contest (as opposed to 34\% in 2014); ${ }^{59}$ the other seats were resolved through private negotiations between the company and the activists.

SSGA objected to the substance of these agreements (which they saw as inducing the company to focus on the short-term), but even more to the process. Procedurally, they believed themselves to be disenfranchised by these private settlements. In its 2016 statement, SSGA made a number of specific proposals as to the duration of such agreements, the requisite holding period for shares held by activists, the pledging of activist shares, and the need for fund-nominated directors to resign in certain circumstances. ${ }^{60}$ Procedurally, SSGA announced they would engage with companies ex post to evaluate

CEO Bill Mc Nabb’s Open Letter to Directors of Public Companies 2017 (https://about.vanguard.com/investmentstewardship/governance-letter-to-companies.pdf) and his 2015 Letter to Independent Chairmen and Lead Directors of Vanguard Portfolio Companies (https://about.vanguard.com/investmentstewardship/CEO_Letter_03_02_ext.pdf).

${ }^{57}$ The leading example is the Commonsense Corporate Governance Principles, which were signed by prestigious names, such as Warren Buffett and the CEOs of General Motors, General Electric, JPMorgan Chase, BlackRock, Vanguard, State Street, and others. These principles emphasized planning for the long-term and the role of long-term asset managers in corporate governance. For a contemporaneous review of these Principles, see "The Commonsense Principles of Corporate Governance Make Sense,” Mondaq Business Briefing, August 10, 2016. A similar group, Focusing Capital on the Long Term, also united some major corporations and institutional investors in an effort to re-orient investment policies toward the long run.

${ }^{58}$ See SSGA, "Protecting Long-Term Shareholder Interests in Activist Engagements” (October 10, 2016).

${ }^{59}$ Id. at 1.

${ }^{60}$ Specifically, SSGA objected to the following:

Duration. SSGA estimated that the duration of most settlement agreements ran from six to eighteen months, and it suggested that the agreements continue for a longer period (but it did not specify the proposed duration).

Share Holding Periods. SSGA argued that "an activist firm should be required to hold its shares for long periods from the date of the settlement to align them with longer-termed shareholders.” Id at 2. 
these settlements. Unfortunately, this resembles locking the barn door after the horse has been stolen. Once a financial engineering strategy has been undertaken or activist directors appointed, these steps are not easily reversed.

Thus, although SSGA's critique won much applause, it did not outline a feasible strategy for the future, and managements engaged by activists would predictably continue to take the course of least resistance and settle privately. Accordingly, the next section will focus on feasible strategies, both to protect the long-term shareholder from disenfranchisement and to reduce the subsidy that informed trading may be providing to fuel activism.

\section{Practical Reforms}

Two basic problems have been identified to this point: (1) Informed trading may represent a hidden subsidy for activism, which could inflate the rate of activism, as activist campaigns may yield some (including the activist’s allies) low-risk profit; and (2) Long-term shareholders (largely diversified pension and mutual funds, but also exchange traded funds) may be disenfranchised, if risk-averse managements would rather privately settle with the activist than undertake a risky fight or enter into broader negotiations with all the shareholders. On the assumption that legislation is unlikely (and Congress dysfunctional), this section will focus on self-help reforms and possible SEC rules on the premise that the least drastic means should be preferred.

\section{A. Protecting Against Disenfranchisement}

Let's start with a realistic assumption: once an activist appears, management cannot be trusted to side with the majority of the shareholders. Management wants to avoid a costly public proxy fight that it could lose and that would likely result in its eventual ouster. Thus, it is prepared to reach a weak, Neville Chamberlain-like compromise: namely, it will offer two seats on its board for “peace in our time.” In

.Minimum Ownership Thresholds. SSGA objected to reduction the activist's stake in the target and asked companies to require directors nominated by activists to tender their resignations if the activists' ownership level fell below a required minimum threshold.

Restrictions on Pledging. SSGA would limit both short sales and pledging of shares by activists, which conduct, it said, could endanger the company's stock price. compensation.

Executive Compensation. SSGA objected to using earnings per share as the primary determinant of CEO 
reality, much as in Neville Chamberlain's case, management seldom gets the peace it sought, because the appointment of activist directors is regularly followed by the departure of the CEO within a year or two. ${ }^{61}$ Still, managements can hope, and so they settle.

Corporate managements also have more reason to fear hedge fund activists than diversified investors, even if the latter hold more stock. This is because undiversified hedge funds hold a small portfolio, are focused on only one or two campaigns at a time, and have shown in the past that they will undertake the costs of a proxy fight. In contrast, diversified investors may own $1 \%$ stakes in hundreds of stocks, have modest staffs, and are unlikely to take action with respect to an individual stock that represents only a small proportion of their portfolio. They may vote for or against the activist, but they are reluctant to incur costs.

In this light, it is impractical to expect an SSGA to take a seat on any of the hundreds of boards that have reason to fear an activist attack in the near future. SSGA does not have sufficient qualified staff to cover the waterfront and monitor closely all the companies in its portfolio. Indeed, even if a corporation were to ask it to place a representative on its board (in order to signal the corporation's willingness to resist activists), SSGA might logically decline, because the presence of an SSGA employee on a corporation's board could restrict its ability to sell that stock (for fear of insider trading liability). Passive investors are passive for a reason: they logically prefer liquidity to control. ${ }^{62}$

What then can we realistically expect of diversified institutional investors? Here are two possibilities: First, investors, such as SSGA and BlackRock, who fear they are being disenfranchised by private settlements, could form (with other similarly-minded institutions) a steering committee and assemble a team of outside directors (who were not their employees) that they could seek to place on corporate boards in the event of an activist attack. This would take some advance preparation, but the

\footnotetext{
${ }^{61}$ A study by FTI Consulting in 2016 found that CEO turnover when activist nominees gain board seats was 34.1\% and $55.1 \%$ over the one and two year period, respectively, following the board appointments. The normal CEO turnover rates are $16.6 \%$ and $30.9 \%$ over a one and two year periods, respectively. See Sonali Basak and Beth Jinks, “Activist investors double chance of CEO exits, study shows,” Bloomberg News, October 12, 2016.

${ }^{62}$ The author has made this argument at considerable length elsewhere. See John C. Coffee, Jr., Liquidity Versus Control: The Institutional Investor As Corporate Monitor, 91 Colum. L. Rev. 1277 (1991). Hedge Funds, being undiversified, are an exception to this generalization.
} 
effort and expense could be shared among the dozen (or more) institutions participating in such a committee. This committee could contact the corporation at the outset of an activist campaign to suggest either its own nominees or its desired to be involved in the settlement process. To be sure, some corporations would not welcome this development (as it would complicate their negotiations), but others might see it as giving management more negotiating leverage. This committee would have no authority to bind its members and would act only when it had the support of a majority of its members.

Second, diversified investors, working with ISS or a similar body, could adopt a shareholderapproved bylaw that would preclude board action either to expand the board's size or elect persons to vacancies on the board under certain circumstances. For example, such a bylaw might seek to restrict such board action in cases where a requisite percentage of the shareholders objected. Consider then a bylaw that applied only if, after an activist filed a Schedule 13D or otherwise “engaged” the company, shareholders representing a larger ownership stake than that announced by the activist in its Schedule 13D were to file a written demand with the corporation within a specified period, asking the board not to settle with the activist by appointing its nominees. In effect, such a bylaw would bar private settlements and require that the matter be settled instead by a shareholder vote at the annual meeting (unless a majority of the objecting shareholders later withdrew their demand). The core idea here is that, in the event of an activist engagement, the diversified shareholders could seek to block private settlements (without their consent) if they filed a demand supported by a larger percentage of shares than the activists held. The filing of such a demand would effectively assert that the activists did not represent the "silent majority" of the shareholders. This bylaw would provide that it could only be amended by shareholder action, but, procedures could be further specified in the bylaw so that these shareholders could withdraw their demand if an acceptable compromise were reached among the activists, the diversified shareholders and corporate management. In reality, such a shareholder demand would be intended to start a three-way negotiation between the activists, the "silent majority", and management. 
Inevitably, there are some legal issues here, but they can be largely solved or outflanked. ${ }^{63}$ In any event, most corporate managements would find it difficult simply to rebuff or challenge such a demand. This demand procedure would give the diversified investor community both flexibility and leverage, as they could first meet with management and negotiate for their own candidate or candidates to join the board, turning to the demand procedure only if they were left unsatisfied. A perceptive corporate management might welcome (and even adopt) such a bylaw, because it would be a clear signal to activists that they would encounter stiff resistance at such a company. ${ }^{64}$ This signal might deter some activist engagements, and that may be an important virtue of this bylaw.

\section{B. Restricting Informed Trading}

Information leakage can injure the corporation and its shareholders in at least two ways: first, premature disclosure may disable the corporation from exploiting opportunities or working out problems, which it could have done if it had more time. The facts of the famous Texas Gulf Sulphur case illustrate this problem, as heavy insider trading forced the company to disclose its extraordinary ore strike before it could buy the mineral rights on the land surrounding its test drill holes. ${ }^{65}$ In other cases, misappropriated

\footnotetext{
${ }^{63}$ First and foremost is the possibility that a shareholder-adopted bylaw may be deemed invalid (at least in Delaware) if it fails to contain language or a provision reserving to the corporation's directors their power to fulfill their fiduciary duties and reach a private settlement in a specific case. See CA, Inc. v AFSCME Employees Pension Plan, 953 A.ad 227, 240 (Del. 2008) (determining that shareholder approved bylaws may not usurp the board's power to exercise its fiduciary duty). Several answers are possible to this objection. First, language could be inserted giving the board such power, but only after they fully consulted with the shareholders filing the demand. Second, if the corporate management sensibly realized that such a provision insulated them, they could, themselves, amend the certificate of incorporation to add the same provision (which would then no longer be subject to such a legal challenge). Or, the board could amend the bylaws themselves (which arguably should be effective). Even if the bylaw could not be fully enforced, it could still have considerable impact on a corporation that did not want to offend its "permanent shareholders."

A second problem is that the solicitation of shareholders to sign such a written demand might be deemed a solicitation subject to the proxy rules. However, several exemptions from the proxy rules seem available here. Rule 14a-2(b)(2), 17 C.F.R. § 240.14a-2(b)(2), exempts solicitations "where the total number selected is not more than ten,” Less than ten institutional investors could easily hold $7 \%$ or $8 \%$ of the issuer's stock. Also, those asking institutional investors to sign such a demand could claim the exemption afford by Rule 14a-2(b)(1) because they would not be seeking proxy authority. The bottom line is that they legal problems here can be solved.

${ }^{64}$ Of course, one impact of such a bylaw or charter provision might be to cause activists to directly approach the institutional investor community and work out their proposal with them before approaching the company. But this is desirable.

${ }^{65}$ See SEC v. Texas Gulf Sulphur, 401 F. 2d 833 (2d. Cir. 1968) (en banc). Essentially, this case held that the SEC could sue corporate managers who traded after a major ore discovery but before its disclosure, but the company's disclosure of the strike, which was hastened by its managers' trading, precluded it from fully realizing all the gains from its discovery.
} 
information may be seized and exploited by others, again injuring the corporation. Second, even if premature disclosure does not injure the corporation, informed trading in the corporation's stock causes its bid/ask spread to widen, and this cost falls on all shareholders. Indeed, even those shareholders who do not trade bear it indirectly, because it raises the cost of capital to the corporation. Small as this cost may be in individual transactions, the aggregate cost across the market is large.

One response to the evidence earlier noted that informed trading occurs regularly once activist nominees (and particularly activist employees) are appointed to the board is to say: enforce the law! If this is unlawful, then arguably there should be criminal prosecutions. But that response, while understandable, may be oversimple. There are both legal uncertainties and enormous problems of proof in relying on criminal sanctions or SEC civil enforcement. This section will briefly survey these problems and then turn to a proposed rule change that would expand the definition of "group" under the Williams Act, in part in order to simplify insider trading enforcement.

1. Legal Uncertainties. Much trading by hedge funds who are planning an engagement with a corporation appears to be lawful. For example, assume that one activist hedge fund (the Mars fund) tells five other funds that it is planning to file a Schedule 13D in 2 weeks, with respect to Widget Corp., which document would list its demands, including that Widget's CEO be replaced. All parties to this communication understand that a significant stock market jump will follow the filing of the Schedule 13D (probably an abnormal return of 7\% or so). But those trading on this information do not violate U.S. law, because they own no fiduciary duty to Widget Corp. Similarly, if at a later point, the Mars fund approaches other activists to support it in its proxy campaign to add three directors to the Widget board, the same conclusion follows: no fiduciary duty is owed to Widget; hence no liability.

But the issues become more complex once Mars successfully appoints two directors to Widget’s board. Now, the directors do owe a fiduciary duty to Widget, and any material, nonpublic information that Mars receives from them (directly or indirectly) makes Mars a potential tippee who is barred from 
trading. Traditionally, from the Supreme Court's decision in Dirks v SEC ${ }^{66}$ to the Second Circuit's decision in Newman ${ }^{67}$ it was necessary for the prosecution to show that the tipper received some “personal benefit” from (or on behalf of) the tippee. This burden could often be easily satisfied. For example, if Mars pays a salary to its employees and asks them to sit on the Widget board, this should suffice to constitute the requisite "personal benefit”. Even if Mars, pays nothing to outside experts, it may still have caused them to receive a director’s salary from Widget, and this too may suffice.

But suppose Mars does not trade. Instead, one of its allies (Jupiter Fund, a fellow "Wolf Pack" member) hears indirectly what Mars' employee on the Widget board has heard at the last board meeting. Jupiter has paid nothing to Mars’ employee, but it probably knows that Mars has compensated him. Jupiter may then have liability on the theory that it knew that the tippee received a "personal benefit”. But if the information now leaks from Jupiter to other funds who do not know the origins of the material information that they learn from the Mars' employee’s relaying the information to Mars, this may be beyond the effective reach of SEC or criminal enforcement.

The prosecutor's burden in proving insider trading has been substantially simplified by a recent Second Circuit decision, United States v. Martoma, ${ }^{68}$ which implies that a "gift" of information made by a tipper (or any successive tippee) to virtually anyone also violates the law, even if no "benefit” is given by the tippee to the tipper. But this decision would still seemingly require that the recipient of the information know that the gift was a fiduciary breach by the tipper.

The point here is that as the chain of tippees lengthens, enforcement becomes more difficult and, eventually, impossible. At some point, remote tippees do not know the source of the information. Also, the director/tipper may have had legitimate reasons for disclosing the information, first to the hedge fund employing the tipper and possibly even to its allies. If so, this employee has not aided and abetted anyone's trading violation, at least when the employee was intending only to discuss the next tactical moves with the rest of fund's management team. In this light, we cannot safely conclude that the

\footnotetext{
${ }^{66} 963$ U.S. 646 (1983)

${ }^{67}$ United States v. Newman, 773 F. 3d 438 (2d Cir. 2014).

68 2017 U.S. App. LEXIS 16084 (2d Cir. August 23, 2017).
} 
increased "leakiness" surrounding companies with hedge fund employees on their boards implies that unlawful insider trading has occurred. It may have, but then again, perhaps not. Still, the widened bid/ask spread is an agency cost (as is the possibility that premature disclosure may cost the company in other ways).

The relevant question thus raised is whether there is a feasible way to reduce this agency cost. In my view, the simplest means to this end would be to expand the concept of "group" under the Williams

Act.

2. Redefining "Group” Here, a word of background is necessary. The driving force behind hedge fund activism is the ability of a "wolf pack" of like-minded investors to assemble quickly to threaten (or undertake) a proxy campaign. ${ }^{69}$ If all the members of the "wolf pack" were deemed to constitute a "group” under Section 13(d)(3) of the Williams Act, the process of "wolf pack" formation would need to slow, some current members would likely refuse to join the group, and other shareholders could enter the negotiations with the issuer to suggest other board candidates. On the face of the SEC's rules under the Williams Act, this informal association of activist investors could easily be deemed a "group,"70 but recent judicial decisions have defined "group” narrowly, refusing to treat activist investors who were discussing parallel action to constitute a group. ${ }^{71}$ Even a joint slate of directors proposed by the same investors has not sufficed to convince at least one court to deem this association of investors a "group". 72 Curiously, earlier decisions had found a "group” whenever investors "reached an understanding to act in

${ }^{69}$ I discuss this theme at much greater length in John C. Coffee, Jr. and Darius Palia, The Wolf at the Door: The Impact of Hedge Fund Activism on Corporate Governance, 41 J. of Corporation Law 545 (2016)

${ }_{70}$ Particular attention needs to be given here to SEC Rule 13d-5(b)(1) (“Acquisition of securities”), which provides as follows:

" $\mathrm{b}(1)$ When two or more persons agree to act together for the purpose of acquiring, holding, voting, or disposing of equity securities of an issuer, the group formed thereby shall be deemed to have acquired beneficial ownership, for purpose of Sections 13(d) and 13(g) of the Act, as of the date of such agreement, of all equity securities of that issuer beneficially owned by any such persons."

This rule recognizes the possibility of a "voting group"- that is, persons who have agreed to act together, for example, to elect one or more directors.

${ }^{71}$ See Hollywood Realty Partners L.P. v. Gotham Partners, L.P., 286 F. 3d 613 (2d Cir 2002)

${ }^{72}$ McVC Draper Fisher Jurvetson Fund, Inc. v. Millennial Partners, L.P., 260 F. Supp. 2d 616, 631-33 (S.D.N.Y. 2003) 
concert." ${ }^{, 73}$ What explains this judicial shift? Possibly, more recent courts have been reluctant to change the balance of advantage in a takeover battle and did not wish to enjoin a lucrative tender offer over an arguably minor disclosure violation.

Today, however, the issue is not whether a tender offer should be blocked because of a possible disclosure shortcoming, but whether an activist-led minority of the shares can assemble a block and preempt the preferences of the more passive majority. In such a context, courts should be more sensitive to the likelihood that persons acting in concert have not had to disclose their identities, plans and stock positions at the time they begin to pressure the board. For example, assume that these hedge funds, each owning 3\% of the target's stock, decide to pressure the target to increase its financial leverage and spin off a third of its assets. If, their decision to act in concert made them a group, they would be required to file a joint Schedule 13D, acknowledging that they were a group and disclosing their plans. But if they can avoid becoming a "group" simply be declaring that they all planned to act independently, then a Section 13D filing would not be required until one of the three crossed the five percent threshold of Section 13(d).

This timing difference is today important because earlier notice would give a greater opportunity for other investors (such as SSGA and other diversified institutional investors) to organize and participate in the negotiations with the issuer. In contrast, in the takeover context, earlier notice only gave the target more time to activate its defenses or seek a white knight.

Even under the narrow view of "group" taken by more recent decisions, there is far more reason to find that a "group" exists when the activists are planning (or threatening) a proxy contest. Proxy contests, by definition, require collective action. In contrast those who simply buy a target's stock in the hopes that there will be a future takeover bid are not acting collectively (even if they regularly communicate). Thus, those who discuss the possibility of asking management to appoint their nominees to the board (with the inherent threat in the background that they will start a proxy contest if rebuffed)

\footnotetext{
${ }^{73}$ See, e.g., GAF Corp. v Milstein, 453 F. 2d 709, 717 (2d Cir. 1971); Wellman v Dickinson, 682 F. 2d 355, 363 (2d Cir. 1982)
} 
seem more properly considered a "group" than those investors who simply purchase the stock, hoping that there will be a takeover bid. Put simply, because the former need to act collectively to succeed, they are more appropriately deemed a "group”.

Nonetheless, the narrowness of the recent cases poses a problem. The best answer to this problem would be a new SEC rule, defining the term "group” in the context of hedge fund activism. Here, I would suggest that such a proposed rule should define group to include:

"any association in fact of persons or entities, formal or informal, that is seeking to appoint directors to the corporation's board, whether through private negotiations or a proxy contest, including any person who has received information or plans with respect to this effort from another group member prior to the public disclosure of the campaign and who subsequently purchased stock of the issuer.,"74

This “group” would include all shareholders who purchased the issuer’s stock after receiving such a private tip from any other group member. This standard accomplishes two things at once: first, it would exclude the public shareholder who only learns from press reports or news media that activists are seeking to advance a slate of board nominees. Such people, even if they strongly support the slate, were not part of the group that organized the campaign. Second, this standard places considerable weight on the private tipping of information by an activist to its allies; this is what fuels the "wolf pack" and thus should define the group. Tips do not occur randomly; they are made to those whose support and loyalty is sought. When the lead activist tells other hedge funds (or other activists) that it is planning to file a Schedule 13D next week with respect to Widget Corp., this is not idle gossip. Rather, this is an informal invitation to form the "group", and the law should so recognize.

If those who receive such a tip and then purchase the target's stock were deemed to be members of a section 13(d) group, the consequence of using the fact of a tip from one activist to another as evidence of a group's formation would be that the existence of the "wolf pack" would have to be disclosed at a much earlier stage. Presumably, the Schedule 13D would have to be amended as each

\footnotetext{
${ }^{74}$ Thus, any person or entity contacted by the lead activist prior to the filing of its Schedule 13D would be deemed a member of this group, if it purchased any shares in the target after that point. No formal acceptance (nor any formal rejection) would count if there were share purchases by the putative group member after this tip and before public disclosure.
} 
additional member "joined" the team. This idea has at least occurred to the SEC. ${ }^{75}$ Some investors would not want to join the "group” (possibly for fear of liability), but this would mean that they could not buy the target's shares (at least prior to the public disclosure of the "group" on the filing of the Schedule 13D). Also, any poison pill adopted by the target in response to this disclosure would restrict all the "group" members, holding them to their current disclosed stake. In short, the "wolf pack" could less easily grow to the size it has reached in some recent cases. Any proxy contest would likely be a closer battle, and other shareholders might petition board to support their nominees instead.

Is there any chance that the SEC would adopt such an expanded definition of "group"? It fits easily within the statutory language and is consistent with the existing rules, but in recent years the SEC has stood mutely on the sidelines in the battles between companies and the activists engaging them. This neutrality may have in part been because the SEC knew that it would take much criticism from either the corporate community or the institutional investor community if it sided with the other side. But today, it is no longer a two-sided battle, as the institutional investor community is itself divided (with activists on one side and the "permanent” shareholder community—i.e., BlackRock, SSGA and Vanguard—on the other). By ignoring the "wolf pack", the SEC is increasingly playing the ostrich, and rendering itself irrelevant.

\section{Impact}

The proposals here made will not stop or cripple hedge fund activism. Nor is that their intent. They should reduce tipping and informed trading, and they are intended to permit the shareholders to restrict private settlements that appoint directors supported (so far as anyone knows) only by the activist “group.” Possibly, these (and other reforms) might incline activist funds not to appoint their own employees to the boards of firms they engage (and that might reduce the impact on the bid/ask spread). Still, these are modest interventions that seek only to reduce the principal agency costs associated with

\footnotetext{
${ }^{75}$ The SEC has recently begun to suggest that collaborative sharing by the hedge funds of information about a campaign aimed at a specific target could "cross the line" and result in the formation of a "group." See Perrie Michael Weiner and Patrick Hummus, "Expect Greater SEC Scrutiny of Activist Hedge Funds That Share Information or Collaborate In Advance of Their Trades,” Law360.com, April 17, 2014 (available at www.law360.com/articles/529294/activist-investors-brace-yourself-for-13d-changes); L. Hoffman, A. Viswanatha, and D. Benoit, "SEC Probes Activist Funds Over Whether They Secretly Acted In Concert," The Wall Street Journal, June 4, 2015.
} 
hedge fund activism. They increase transparency and shareholder rights, but they do not preclude activism.

\section{Stockholder Wealth Maximization Versus the Public Morality}

Traditionally, the debate over the degree to which management may consider the interests of other stakeholders or the public interest was essentially framed in legal terms about the nature of managerial authority and the scope of the business judgment rule. In the 1980's, the American Law Institute united its members (at least for that time) behind the following standard in Section 2.01 of its Principles of Corporate Governance:

"Section 2.01. The objective and conduct of the corporation.

(a)[A] corporation should have as its objective the conduct of business activities with a view to enhancing corporate profit and shareholder gain

(b) Even if corporate profit and shareholder gain are not thereby enhanced, the corporation, in the conduct of its business:

(1) Is obliged, to the same extent as a natural person, to act within the boundaries set by law;

(2) May take into account ethical considerations that are reasonably regarded as appropriate to the responsible conduct of business; and (3) May devote a reasonable amount of resources to public welfare, humanitarian, educational and philanthropic purposes."76

In essence, this says: maximize shareholder value, but subject to side constraints that permit (but do not require) management to consider the public morality and ethical norms and devote some resources to charitable purposes. Although much in the ALI Corporate Governance Project attracted controversy, this provision united the ALI's prestigious membership and attracted little debate or controversy. ${ }^{77}$

But the problem with this provision today is that it may have become irrelevant. We are no longer concerned with what is legally permissible or otherwise protected by the business judgment rule, but by

\footnotetext{
${ }^{76}$ See ALI, Principles of Corporate Governance, Section 2.01 (1981). Note that Section 2.01(a) does not use the verb "maximize", but does otherwise define the corporate objective as "enhancing corporate profit and shareholder gain". That, rather than serving the public or "doing good", was made the central objective of the corporation. Still, Section 2.01(b)(2) gave the board discretion to take into account "ethical considerations", but only those "reasonably regarded as appropriate to the responsible conduct of business." Thus, purely "personal” ethical norms (for example, vegetarianism) cannot justify a deviation from shareholder wealth maximization.

${ }_{77}$ As best as I can recall, there was some resistance within the ALI to any use of the word "maximization" (and the resulting need to discuss "short-term" versus "long-term" issues if that word was used), but no objection at all to the propositions that the corporation had to obey the law and should seek to protect employees, consumers, and others from safety and health hazards, even if it did not increase profits or stock price.
} 
whether a deviation from a policy of pure shareholder wealth maximization will attract an activist attack. Put differently, management's concern today in responding to ethical concerns is not that they will be sued, but that they will be voted out of office if they materially deviate from short-term profit maximization.

1.NRG Energy: A Case Study. A dramatic example of a company caught in the crossfire between different varieties of activist pressure is supplied by NRG Energy, Inc., the nation’s second-largest electricity producer. ${ }^{78}$ Under its former CEO, David Crane, NRG had announced a policy of shifting from “dirty” to "clean” energy, setting the ambitious goal of reducing its emissions of carbon dioxide by 50\% by 2030 , and by $90 \%$ by $2050 .{ }^{79}$ In pursuit of this goal, Crane caused NRG to purchase renewable energy assets - basically, small solar and wind power companies. These steps made NRG the darling of environmentalists, but NRG’s stock price sank significantly (in part because of volatile natural gas prices). Eventually, this caused NRG’s board in 2016 to replace Crane with NRG's chief operating officer, Mauricio Gutierrez, who, although he also favored a shift towards renewable energy, began an aggressive cost-cutting program to appease dissatisfied shareholders.

Then, early in 2017, Elliott Management and Bluescape Energy Partners, both well-known activists, purchased stakes in NRG totaling 9.4\% and placed two nominees on NRG's board. These two new directors were then named to a newly created "business review committee” that was seeking cost reductions and evaluating possible asset sales by NRG. Both Elliott and Bluescape saw NRG's shift to cleaner energy as overly costly and had urged NRG to sell its renewable energy assets as a way of ending what they saw as a misadventure in political correctness. ${ }^{80}$ In addition, one of their nominees to the NRG board, Barry Smitherman, an outspoken former Texas utility regulator, attracted much attention by describing himself as a crusader who had been "battling this global warming hoax for 6 years now.»81

\footnotetext{
${ }^{78}$ See Ed Crooks, “Activists clash over direction for NRG Energy,” Financial Times, April 21, 2017 (https://www.ft.com/content/89417bal-); Diane Cardwell and Alexandra Stevenson, "NRG, a Power Company Leaning Green, Faces Activist Challenge,” DealBook, New York Times, April 7, 2017.

${ }^{79}$ See Cardwell and Stevenson, supra note 78.

${ }^{80}$ See Crooks, supra note 78, at 1; see also Cardwell and Stevenson, supra note 78.

${ }^{81}$ Id. at 2 (citing comments by Barry Smitherman, an NRG director appointed by these activists).
} 
His view that global warming was a "hoax" alienated another large investor in NRG, the New York City Controller (which held 0.4\% of NRG's share on behalf of New York City's pension fund), and it asked investors not to re-elect Smitherman. In response, Elliott made clear that it favored selling off NRG's renewable energy business. ${ }^{82}$ In short, NRG's management had sought to respond to "climate change” pressure from reformers and the public by shifting to cleaner energy, but it found itself caught in a crossfire and facing a united "wolfpack" of hedge fund activists, who saw coal power as cheaper and had no desire to appease "climate change" reformers.

Ultimately, the hedge fund activists won a resounding victory at NRG, as the company announced in July, 2017 that it would sell up to \$4 billion of its renewable energy assets in an effort "to undo a bold, but unsuccessful plan, under two previous NRG chief executives to diversify away from coal and gas into wind and solar., ${ }^{\text {,3 }}$ NRG's stock price soared immediately on this announcement. ${ }^{84}$ Having made a short-term (and sizable) profit, Elliott then sold off a large block of its NRG holdings in late $2017 .^{85}$

What is the message here? To activists, it is that a management that gets too far out in advance of its shareholders in pursuit of social or public interest goals will be disciplined. But the electric power industry as a whole now faces a dilemma. Although the industry realizes that it must shift to cleaner energy sources, it fears copycat attacks from other activists, using Elliott’s playbook. As a result, the industry is stalemated. Someday, NRG may yet be regarded as a leader. For the time being, however, it is a prophet rejected in its own time.

Earlier, it was seen that hedge fund activism was slowing the movement to greater gender diversity in the boardroom. ${ }^{86}$ The same phenomenon is even more visible in the NRG story: the discretion

\footnotetext{
${ }^{82}$ Diane Cardwell and Alexandra Stevenson, supra note 78.

${ }^{83}$ See Russell Gold, "NRG to Sell Assets, Slash Costs, Bowing to Activist Pressure”, The Wall Street Journal, July 12, 2017.

${ }^{84}$ The one day gain was an extraordinary 29\%. Id. The stock has continued to rise during the Fall of 2017.

${ }^{85}$ Elliott Management reported in a Schedule 13D filing that it had sold 5.6 million shares of NRG in August, 2017, apparently bringing its stake down from 5.7\% to 4.4\%. See http://marketrealist.com/2017/10/a-look-at-NRGenergys-price-target-valuation-and-more/).

${ }^{86}$ See text and notes supra at notes 53 to 55 .
} 
that directors and managers once possessed to consider the public interest and morality is shrinking as a result of hedge fund activism. Whether this constitutes an agency cost can be debated, but over the long run corporations that disdain the public morality are likely to encounter more problems and crises than those that are sensitive to it.

2.The shift to passive investing. American investors are shifting away from actively managed mutual funds to indexed and passive vehicles that make little effort to pick "winners” (but have low costs and enable investors to invest in the market generally). Firms, such as Vanguard and BlackRock, are thus receiving enormous cash inflows (and, as a result, hold increased voting power). Lazard reports that over the most recent 12-month period, “passive equity funds took in $\$ 500$ billion of net inflows after bringing in $\$ 250$ billion inflows in the prior 12-month period. ${ }^{\circledR 7}$ For the future, passive investors appear likely to hold the balance of power in future battles between activist funds and corporate management.

The leader among indexed investors has long been Vanguard, which has also frequently expressed misgivings about activist funds. As a participant in corporate democracy, Vanguard has traditionally been a low-profile player, generally abstaining on shareholder proxy proposals made by environmentalists and other social reformers. ${ }^{88}$ But this has recently changed. Vanguard no longer regularly abstains. Generally, it does not support proposals made by social reformers, but there are two major exceptions: proposals on gender diversity and climate change. At least in 2017, Vanguard has shifted to support these proposals. ${ }^{89}$

Nor is it alone. Lazard also has reported that BlackRock and State Street have also voted in favor of proposals on gender diversity and climate risk. ${ }^{90}$ The three -- BlackRock, State Street, and Vanguard -are the leading representations of the self-described "permanent shareholders" and regular critics of the "short-termism" of activist hedge funds. Apparently, they also now share a perspective on at least some

\footnotetext{
${ }^{87}$ See Lazard Shareholder Advisory Group, “Review of Shareholder Activism-3Q 2017,” at 1.

${ }^{88}$ According to Proxy Insight Ltd., a consulting firm, "Vanguard's 2017 voting record shows a distinct shift away from Abstaining on ESG proposals.” ("ESG” stands for “environmental, social and governance” proposals). In 2016, Vanguard abstained on 25\% of such proposals, but this rate fell to only 3.2\% in 2017. See Email to author from Seth Duppstadt of Proxy Insight, dated October 4, 2017.

${ }^{89}$ Id. In 2017, Vanguard supported a "board diversity" report in $80 \%$ of its votes.

${ }^{90}$ See Lazard's Shareholder Advisory Group, supra note 87, at 1.
} 
social issues (namely, gender diversity and climate change). At bottom, this reflects their common view that there are ethical policies that should not be subordinated to shareholder wealth maximization (possibly because they believe these policies are consistent with long-term shareholder wealth maximization, possibly because they sense their own shareholders favor such policies, or possibly for both reasons).

Still, even if these diversified institutional investors share common ground, they do not always agree. This was evident in the recent campaign by Trian Fund Management to place its founder, Nelson Peltz, on the board of Proctor \& Gamble ("P\&G") in the most expensive proxy contest yet fought. ${ }^{91}$ Trian held a $\$ 3.5$ billion stake in P\&G, but this came to only 1.5\% of the stock, as P\&G's market capitalization was around \$235 billion. An unusually high percentage of stock (probably 40\%) was held by individual investors (including many present and former P\&G employees), and they traditionally vote with management. ${ }^{92}$ Another $40 \%$ (or more) was held by institutional investors, who heavily preferred Peltz. This left the decisive balance of the power in the hands of P\&G's three largest shareholders: Vanguard, BlackRock and State Street, who collectively held more than $17 \%$ of its stock. ${ }^{93}$ As it turned out, Vanguard, P\&G’s largest shareholder, backed management, while BlackRock and State Street supported Peltz. ${ }^{94}$ This division allowed P\&G to eke out a narrow $1 \%$ victory.

The message here is that these three "permanent shareholders” will sometimes be able to protect management -- if they agree. But, even if they agree, they cannot always protect management from an activist attack. The Trian Fund acted, more or less, alone and did not assemble a "wolf pack". Those activists that do assemble a "wolf pack" may be able to aggregate $20 \%$ or more of the shares (particularly in companies smaller than P\&G). This may enable them to outvote even a united triumvirate of Vanguard,

\footnotetext{
${ }^{91}$ For an overview of this battle, see Michelle Celarier, "Procter \& Gamble’s Win is Rare in a year of Activist Gains,” Institutional Investor, October 11, 2017.

${ }^{92}$ See Rob Cox “P\&G counting on an investor electoral college,” Breakingviews, Reuters, October 6, 2017 (providing breakdown of P\&G stock ownership). ${ }_{93} \underline{\text { Id. }}$.

${ }^{94}$ For the conclusion that Vanguard backed P\&G, while BlackRock and State Street did not, see Svea HerbstBayliss and Siddharth Cavale, "Procter \& Gamble foresees proxy war victory; Peltz refuses to concede," Reuters, Business News, October 10, 2017; Lauren Hirsch, "P\&G says shareholders reject Peltz's bid for board seat by slim margin,” CNBC, October 10, 2017.
} 
BlackRock and State Street (and in most cases the percentage of stock held by loyal individual shareholders will be well below the $40 \%$ level at P\&G). Nor will a Vanguard, BlackRock or State Street be willing to incur the high transaction costs that the Trian undertook. To be sure, if there is a proxy contest, corporate management will willingly incur these coordination costs in the hopes of activating an alliance with its “permanent” shareholders. Nonetheless, the clearest lesson of recent activist “engagements" is that a risk averse management would usually rather settle than fight and thus avoid proxy contests, if possible. In this light, one implication of the $P \& G$ battle is that even the "permanent shareholders” may not support management, and certainly this will make management even more prepared to settle.

In the United Kingdom, the practice long ago developed among institutional investors that they could look to the institution with the largest stake in the company to organize the others. ${ }^{95}$ But no such norm has developed in the U.S., where many institutions would prefer to sit on the fence, deciding how to vote only at the end of the contest. Possibly, one answer might be that the "permanent shareholders" should create their own equivalent to Institutional Shareholder Services (or “ISS”), which, itself, tends to side with the activist funds. But that step would require a larger commitment than the permanent shareholders seem yet prepared to make. For the present, at least, “permanent” shareholders may be the critical constituency, but they lack a motivated leader.

3.Where Are We Left? Procter \& Gamble has shown that a large company with a high level of loyal individual shareholders can defeat an activist (but just barely). Contemporaneously, General Electric, an even larger and possibly more troubled company, placed a Trian Fund nominee on its board. ${ }^{96}$

\footnotetext{
${ }^{95}$ Bernard S. Black and John C. Coffee, Jr., Hail Britannia? Institutional Investor Behavior Under Limited Regulation, 92 Mich. L. Rev. 1997 (1994) (finding that in the British securities marketplace, large indexed institutions typically owned a percentage -- say $1 \%$-- of most corporations' stock that reflected their share of the overall British equity market and those firms that were "overweighted" -- i.e., that owned more than that percentage of the company (say $2 \%$ or $3 \%$ ) -- would be expected to lead any institutional challenge to management of the company).

${ }_{96}^{96}$ General Electric Co. added Trian’s chief investment officer, Ed Garden, to its board just days before the Procter \& Gamble vote was announced. See Michael Brown, "Peltz-P\&G Battle Nears a Close as Firm Claims a Victory at General Electric,” TheStreet.com, October 9, 2017. Over recent years, G.E.’s stock price has declined considerably more than P\&G’s stock price.
} 
Thus, although the outcome in contested cases may vary, a pattern of private negotiated settlements seems likely to persist.

None of this should surprise any reader of Mancur Olson's classic, The LOGIC OF COLLECTIVE ACTION ${ }^{97}$ It demonstrated that a well organized minority will normally defeat a larger, but more diffuse majority. Activists are the paradigm of a concentrated minority, and other shareholders are highly diffuse (and passive). Although there may be many reasons why hedge fund activists are well organized and successful, one of them appears to be that they can effectively share material, non-public information. That reason needs to be addressed.

\section{$\underline{\text { Conclusion }}$}

Some leading economists argue that management should maximize not shareholder value, but shareholder welfare. ${ }^{98}$ Unfortunately, that will remain an unrealizable and utopian ideal under current institutional structures in which shareholder voting is controlled by institutional managers compensated to maximize short-term return. The most that can be anticipated is that “permanent shareholders' (i.e., largely indexed institutional shareholders, such as Vanguard and BlackRock) may sometimes resist activists focused largely on the short-term. That goal, however, requires assistance.

Hedge fund activism may, on balance, be for the better or the worse. No bottom line assessment is here offered. But it is the beneficiary of a perverse subsidy to the extent that informed trading accompanies it and benefits at least some of those associated with it.

Both the problems identified in this article -- (1) the prevalence of informed trading, and (2) the ability of an organized minority to preempt the majoritarian preference -- can be addressed by legal rules and reforms that will not preclude, or even seriously chill, legitimate shareholder activism. Also, to the extent that this article shines sunlight on the practice of nominating hedge fund employees to corporate boards and shows that in-house nominees result in greater information leakage, this evidence may

\footnotetext{
${ }^{97}$ See Mancur Olson, Jr., THE LOGIC OF COLLECTIVE ACTION: Public Goods and The Theory of Groups (1965).

${ }^{98}$ Oliver Hart and Luigi Zingales, “Companies should maximize Shareholder Welfare Not Shareholder Value,” ECGI Working Paper No. 521 (2017), (available at SSRN: https://ssrn.com/abstract=3004794) (August 1, 2017)
} 
embarrass hedge funds into changing their nominating practices. As usual, sunlight may be the best disinfectant. Still, to the extent that reforms are needed (particularly to restrict informed trading), it is a safe prediction that they will be intensely resisted. 


\section{about ECGI}

The European Corporate Governance Institute has been established to improve corporate governance through fostering independent scientific research and related activities.

The ECGI will produce and disseminate high quality research while remaining close to the concerns and interests of corporate, financial and public policy makers. It will draw on the expertise of scholars from numerous countries and bring together a critical mass of expertise and interest to bear on this important subject.

The views expressed in this working paper are those of the authors, not those of the ECGI or its members. 


\section{ECGI Working Paper Series in Law}

\section{Editorial Board}

Editor

Consulting Editors

Editorial Assistants
Luca Enriques, Allen \& Overy Professor of Corporate Law, Faculty of Law, University of Oxford

John Coates, John F. Cogan, Jr. Professor of Law and Economics, Harvard Law School

Paul Davies, Senior Research Fellow, Centre for Commercial Law, Harris Manchester College, University of Oxford

Horst Eidenmüller, Freshfields Professor of Commercial Law, University of Oxford

Amir Licht, Professor of Law, Radzyner Law School, Interdisciplinary Center Herzliya

Roberta Romano, Sterling Professor of Law and Director, Yale Law School Center for the Study of Corporate Law, Yale Law School

Tamas Barko , University of Mannheim

Julia Keith, University of Mannheim 


\section{Electronic Access to the Working Paper Series}

The full set of ECGI working papers can be accessed through the Institute's Web-site (www.ecgi.org/wp) or SSRN:

Finance Paper Series http://www.ssrn.com/link/ECGI-Fin.html

Law Paper Series http://www.ssrn.com/link/ECGI-Law.html 